\title{
Synergistic combination of chemo-phototherapy based on temozolomide/ICG-loaded iron oxide nanoparticles for brain cancer treatment
}

\author{
YOUNG MIN KWON ${ }^{1}$, JAE-YOUNG JE ${ }^{2}$, SEUNG HEON CHA ${ }^{3}$, YUNOK OH $^{2}$ and WON HO CHO 3 \\ ${ }^{1}$ Department of Neurosurgery, Dong-A University College of Medicine and Dong-A Medical Center, Busan 49201; \\ ${ }^{2}$ Department of Marine-Bio Convergence Science, Pukyong National University, Busan 48547; \\ ${ }^{3}$ Department of Neurosurgery and Medical Research Institute, Pusan National University Hospital and \\ Pusan National University School of Medicine, Busan 49241, Republic of Korea
}

Received January 18, 2018; Accepted June 24, 2019

DOI: $10.3892 /$ or.2019.7289

\begin{abstract}
Chemo-photothermal therapy for cancer treatment has received increasing attention due to its selective therapeutic effects. In the present study, the anticancer effects of drug-loaded $\mathrm{Fe}_{3} \mathrm{O}_{4}$ magnetic nanoparticles (MNPs) by chemo-photothermal therapy on U-87 MG human glioblastoma cells was investigated. Anticancer drug-loaded $\mathrm{Fe}_{3} \mathrm{O}_{4} \mathrm{MNPs}$ were prepared by loading temozolomide (TMZ) and indocyanine green (ICG), and were characterized by X-ray diffraction, UV-vis spectroscopy, thermal gravimetric analysis, transmission electron microscope, as well as drug-loading capacity. Following treatment with near-infrared (NIR) light irradiation, the administration of $\mathrm{Fe}_{3} \mathrm{O}_{4}$-TMZ-ICG MNPs resulted in the apoptosis of U-87 MG glioblastoma cells through the generation of reactive oxygen species. Western blot analysis and reverse transcription-quantitative polymerase chain reaction revealed that $\mathrm{Fe}_{3} \mathrm{O}_{4}$-TMZ-ICG MNPs with NIR laser irradiation lead to significantly enhanced anticancer effects on U-87 MG glioblastoma cells through the modulation of intrinsic and extrinsic apoptosis genes, including Bcl-2-associated $\mathrm{X}$ protein, Bcl-2, cytochrome $c$, caspase-3, Fas associated via death domain and caspase-8. These results suggest that $\mathrm{Fe}_{3} \mathrm{O}_{4}-\mathrm{TMZ}-\mathrm{ICG}$ MNPs may be potential candidates when administered as chemo-phototherapy for the treatment of brain cancer.
\end{abstract}

Correspondence to: Professor Yunok Oh, Department of Marine-Bio Convergence Science, Pukyoung National University, 365 Sinseon-ro, Nam-Gu, Busan 48547, Republic of Korea

E-mail: siyo565@gmail.com

Dr Won Ho Cho, Department of Neurosurgery and Medical Research Institute, Pusan National University Hospital and Pusan National University School of Medicine, 179 Gudeok-ro, Seo-Gu, Busan 49241, Republic of Korea

E-mail:mdcwh@naver.com

Key words: magnetic nanoparticles, indocyanine green, temozolomide, phototherapy, apoptosis

\section{Introduction}

Glioblastoma (GBM) is the most common primary brain tumor of the central nervous system and has a high mortality rate, with a $4.5 \%$ 5-year relative survival rate in the US following diagnosis (1-3). A variety of cell types with fast growth potential in GBM and the blood-brain barrier (BBB), which controls the transportation of drugs, including antibodies, are major obstacles of GBM treatment $(4,5)$. Thus, the development of a drug delivery system for GBM treatment is urgent to overcome issues associated with the BBB (6). Chemotherapy along with surgery and radiation therapy is the conventional methods for the treatment of patients with GBM (7). Temozolomide (TMZ), a commonly used oral anticancer drug inhibits the viability of malignant glioma cells with increased permeability through the BBB (8). Although TMZ can penetrate BBB, it shows low cytotoxicity against human glioma cells due to several cellular mechanisms of drug resistance (9). Therefore, a strategy for overcome this problem is required to increase the therapeutic efficacy of TMZ.

Chemotherapy in combination with phototherapy is considered an effective approach for treating brain cancer as of its minimal invasiveness (10). Photothermal therapy uses long-wavelength near-infrared (NIR) light with an absorption range, which allows a minimally invasive target treatment for tumor sites without affecting normal cells (11). It was reported that chemotherapeutic efficacy is generally increased in combination with photothermal therapy since the cytotoxicity of chemotherapeutic agents and drug delivery into cancer cells are enhanced at elevated temperatures (12-14). Currently, a number of inorganic and organic NIR photothermal agents, including metal-based particles such as Au $(15,16), \mathrm{Ag}(17), \mathrm{Pt}(18,19)$, and $\mathrm{Cu}$ (20), graphene, and carbon-based nanomaterials (21), have been developed. However, these agents have drawbacks such as high toxicity and low photothermal conversion efficacy in the NIR range.

Magnetic nanoparticles (MNPs) as an effective cancer therapeutic agent and diagnostic contrast nanocomposite are widely applied the in biomedical field (22). Surface modifications of MNPs by introducing functional groups increase 
the efficacy of cancer therapy and bio-imaging through high drug-loading efficacy of MNPs and diagnostic contrast agent (23). In addition, as $\mathrm{Fe}_{3} \mathrm{O}_{4}$ MNPs possess broad absorption in the NIR range, they can be applied for photothermal therapy (24). Recently, studies have reported the photothermal conversion process of $\mathrm{Fe}_{3} \mathrm{O}_{4}$ MNPs based on the photoluminescence emission in the NIR region $(25,26)$; however, few studies have sought to elucidate photothermal properties and conversion mechanism. $\mathrm{Fe}_{3} \mathrm{O}_{4}$ MNPs with a good photothermal conversion efficacy in the NIR region and low toxicity have been developed, and exhibited higher photothermal conversion efficiency than other photoabsorbers, such as noble metal-, carbon- and organic compound-based nanomaterials (27). Furthermore, efficient photothermal-induced hyperthermia using functionalized MNPs can induce synergistic anticancer effects in combination with chemotherapy (28).

Cancer cells are more vulnerable than normal cells due to their immature and disorganized vasculature (29-31). Thus, it is a feasible strategy for irreversible cellular damage through increasing therapeutic temperature $\left(42-47^{\circ} \mathrm{C}\right)$ in the tumor region by photothermal therapy, leading to cellular apoptosis (32). Nanoparticle-mediated NIR thermal therapy depends on photothermal conversion efficacy and laser dosage (33). Additionally, the perfusion of blood and cellular membrane permeability can be improved by increasing the temperature in the tumor region by photothermal-induced local hyperthermia; thereby, the efficacy of drug delivery into the specific intracellular region is enhanced $(34,35)$.

On the contrary, the photothermal effects of $\mathrm{Fe}_{3} \mathrm{O}_{4}$ MNPs alone is usually insufficient to deliver appropriate thermal energy because of inevitable laser light scattering and relatively poor specificity to target tumor area (36). To overcome these problems, the present study proposed ICG- and TMZ-loaded $\mathrm{Fe}_{3} \mathrm{O}_{4}$ MNPs as a multimodal cancer therapeutic agent. ICG, an FDA-proved bifunctional NIR fluorescence dye, acts as a photothermal agent and photodynamic photosensitizer under NIR laser irradiation and can convert absorbed NIR light to thermal energy and reactive oxygen species (ROS) that are essential for photothermal and photodynamic therapy (37). However, its poor photo-stability is a major limiting factor for clinical application. In this study, we subsequently constructed TMZ-and ICG-loaded $\mathrm{Fe}_{3} \mathrm{O}_{4}\left(\mathrm{Fe}_{3} \mathrm{O}_{4}\right.$-TMZ-ICG) MNPs for NIR laser-induced chemo-photothermal-photodynamic therapy (chemo-phototherapy) and evaluated its anticancer effects on U-87 MG glioblastoma cells through ROS-mediated apoptosis under NIR light irradiation. Considering these factors, the combination of chemo-phototherapy using $\mathrm{Fe}_{3} \mathrm{O}_{4}$-TMZ-ICG MNPs could be an effective approach to develop an efficient technique for improved and effective brain cancer treatment.

\section{Materials and methods}

Materials. Iron(III) acetylacetonate [Fe(acac) 3 , 1,2-hexadecanediol $(90 \%)$, oleic acid $(90 \%)$, oleylamine $(70 \%)$, 1-octadecene (90\%), cyclohexane, 1-hexanol, Triton X-100, tetraethyl orthoslicate (TEOS), ammonium hydroxide, 3-glycidyloxypropyl trimethoxysilane (GPTMS), 4-formylphenylboronic acid (FPBA), polyethylenimine (PEI, $50 \mathrm{wt} \%$ solution in water), trimethylamine, tetrahydrofuran and TMZ were obtained from Sigma-Aldrich (Merck KGaA).
Indocyanine green (ICG) was purchased from Thermo Fisher Scientific, Inc. Toluene, absolute ethanol ( $\geq 99.5 \%)$, n-hexane $(\geq 99 \%)$ and dimethyl sulfoxide (DMSO) were obtained from Duksan Company. All commercial chemicals were used without further purification.

Preparation of $\mathrm{Fe}_{3} \mathrm{O}_{4}-\mathrm{TMZ}-\mathrm{ICG}$ MNPs. The $\mathrm{Fe}_{3} \mathrm{O}_{4}$ magnetic core was synthesized by well-established thermal decomposition method (38). In brief, Fe(acac) 3 (3 mmol), 1,2-hexadecanediol (10 mmol), 1-octadecene $(20 \mathrm{ml})$, oleic acid $(6 \mathrm{mmol})$ and oleylamine were stirred under nitrogen atmosphere and the resulting solution was heated to $100^{\circ} \mathrm{C}$ for $30 \mathrm{~min}$. Then, the temperature was slowly increased to $200^{\circ} \mathrm{C}$ and stirred for $2 \mathrm{~h}$. Subsequently, the mixture was refluxed at $320^{\circ} \mathrm{C}$ for $1 \mathrm{~h}$ with vigorous stirring and cooled down to room temperature. The products were precipitated by the addition of excess ethanol $(99.5 \%)$ and purified by washing with n-hexane (99\%) and ethanol repeatedly. The obtained materials were separated by centrifugation at 7,000 x g for $20 \mathrm{~min}$ at room temperature and re-dispersed in n-hexane.

The water soluble silica coated $\mathrm{Fe}_{3} \mathrm{O}_{4} @ \mathrm{SiO}_{2}-\mathrm{NH}_{2}$ MNPs were prepared by the hydrolysis of TEOS (39) and the condensation reaction of GPTMS (40). First, $250 \mathrm{mg} \mathrm{Fe}_{3} \mathrm{O}_{4}$ MNPs was ultrasonically dispersed in a mixture of $20 \mathrm{ml}$ cyclohexane, $4 \mathrm{ml} \mathrm{1-hexanol,} 5 \mathrm{ml}$ of Triton X-100 and $0.85 \mathrm{ml}$ of water for $15 \mathrm{~min}$ at room temperature. To this, a $2.5 \mathrm{ml}$ TEOS was dropped into the solution, and was vigorously stirred for $6 \mathrm{~h}$ at room temperature. Subsequently, a $0.5 \mathrm{ml}$ ammonia solution ( $28 \%$ in water) was added and the solution was further stirred for $24 \mathrm{~h}$. The precipitate was separated by an external magnet and washed with ethanol. The obtained product was dried in a vacuum oven at $60^{\circ} \mathrm{C}$. Afterwards, $200 \mathrm{mg} \mathrm{Fe} \mathrm{O}_{4} @ \mathrm{SiO}_{2} \mathrm{MNPs}$ was dispersed in $80 \mathrm{ml}$ of anhydrous toluene and sonicated for $30 \mathrm{~min}$ at room temperature, and then $2 \mathrm{ml}$ GPTMS was slowly dropped to this suspension under nitrogen atmosphere. Next, the mixture was stirred at $80^{\circ} \mathrm{C}$ for $24 \mathrm{~h}$. After $24 \mathrm{~h}$, the precipitate was separated by an external magnet and washed with toluene and ethanol, and then dried in vacuum oven overnight at $60^{\circ} \mathrm{C}$.

Subsequently, $\mathrm{Fe}_{3} \mathrm{O}_{4} @ \mathrm{SiO}_{2}-\mathrm{NH}_{2} \mathrm{MNPs}$ for the drug and photosensitizer loading were modified with PEI and FPBA for ICG and TMZ conjugations, according to previous reports (41). First, PEI conjugation onto $\mathrm{Fe}_{3} \mathrm{O}_{4} @ \mathrm{SiO}_{2}-\mathrm{NH}_{2}$ MNPs was performed via an epoxy ring opening reaction. $200 \mathrm{mg} \mathrm{Fe} \mathrm{O}_{4} @ \mathrm{SiO}_{2}-\mathrm{NH}_{2}$ MNPs was added in $1.5 \mathrm{ml}$ ethanol containing $0.0025 \mathrm{mg} / \mathrm{ml} \mathrm{PEI}$ and the dispersion was refluxed at $70^{\circ} \mathrm{C}$ for $24 \mathrm{~h}$. After centrifugation at $7,000 \mathrm{x} \mathrm{g}$ for $20 \mathrm{~min}$ at room temperature, the precipitate was washed with ethanol and water for several times and dried at $70^{\circ} \mathrm{C}$ for $10 \mathrm{~h}$. Then, 4-FPBA groups were grafted onto the surface of $\mathrm{Fe}_{3} \mathrm{O}_{4} @ P E I$ MNPs. 200 mg Fe $\mathrm{O}_{4} @$ PEI MNPs was dispersed in $300 \mathrm{ml}$ methanol/acetic acid (124:1), after which $200 \mathrm{mg}$ FPBA was added. The mixed solution was stirred at $40^{\circ} \mathrm{C}$ for $10 \mathrm{~h}$. To eliminate the unstable Schiff base, $200 \mathrm{mg}$ triethylamine was added to the resulting solution and stirred at $40^{\circ} \mathrm{C}$ for $10 \mathrm{~h}$. The resultant $\mathrm{Fe}_{3} \mathrm{O}_{4} @$ PEI-FPBA MNPs were collected and washed several times with water and ethanol.

For drug loading, $\mathrm{Fe}_{3} \mathrm{O}_{4} @$ PEI-FPBA MNPs were modified with TMZ in the presence of succinic anhydride coupling agent (42). 20 mg Fe $\mathrm{O}_{4} @$ PEI-FPBA MNPs was ultrasonically dispersed in $5 \mathrm{ml}$ methanol containing with $1 \mathrm{mg}$ of TMZ for 
$10 \mathrm{~min}$. Then, the mixture was stirred at $35-40^{\circ} \mathrm{C}$ for $12 \mathrm{~h}$. The resultant $\mathrm{Fe}_{3} \mathrm{O}_{4}$-TMZ MNPs were isolated by the removal of methanol and washed several times with methanol and water. Finally, for the photosensitizer loading, $1 \mathrm{mM}$ ICG solution in DMSO was added in the $\mathrm{Fe}_{3} \mathrm{O}_{4}$-TMZ MNPs aqueous dispersion solution with a final DMSO concentration of $10 \%$ by volume and heated at $4{ }^{\circ} \mathrm{C}$ for $12 \mathrm{~h}$. The obtained products were collected and washed several times with water and ethanol, and then stored in distilled water for further use.

Characterization of $\mathrm{Fe}_{3} \mathrm{O}_{4}-\mathrm{TMZ}-\mathrm{ICG} M N P$ s. The crystal structures of the synthesized inorganic $\mathrm{Fe}_{3} \mathrm{O}_{4}$ and $\mathrm{SiO}_{2}$-coated with $\mathrm{Fe}_{3} \mathrm{O}_{4}$ MNPs were analyzed by X-ray diffraction (XRD; X'Pert-MPD System; Philips Healthcare). The optical properties of modified $\mathrm{Fe}_{3} \mathrm{O}_{4}$ MNPs were observed under UV-vis spectroscopy (V-670; JASCO International Co., Ltd.). The quantities of organic functional groups and residual $\mathrm{Fe}_{3} \mathrm{O}_{4}$ content in the $\mathrm{Fe}_{3} \mathrm{O}_{4}$-TMZ-ICG MNPs were measured by thermal gravimetric analysis (TGA; TGA 7, Pyris 1; PerkinElmer, Inc.). Thermal curves of MNPs were measured with a heating rate of $10^{\circ} \mathrm{C} / \mathrm{min}$ from room temperature to $600^{\circ} \mathrm{C}$ under a nitrogen atmosphere.

TMZ and ICG loading contents onto the modified $\mathrm{Fe}_{3} \mathrm{O}_{4}$ MNPs. The TMZ and ICG loading contents onto the modified $\mathrm{Fe}_{3} \mathrm{O}_{4}$ MNPs were determined by UV-vis spectroscopy (43). First, to determine TMZ loading efficiency, $\sim 1.5 \mathrm{mg}$ of $\mathrm{Fe}_{3} \mathrm{O}_{4}$-TMZ MNPs was transferred to $10 \mathrm{ml}$ volumetric flask, and dissolved in $0.1 \mathrm{~N}$ hydrochloric acid $(25 \mu \mathrm{g} / \mathrm{ml})$ using an ultrasonic bath. The dispersion was centrifuged at $10,700 \mathrm{x} \mathrm{g}$ for $20 \mathrm{~min}$ at room temperature. The amount of loaded TMZ was determined by the difference in optical absorbance at $328 \mathrm{~nm}$ between the total amount of TMZ initially added to formation and the amount of free TMZ in the supernatant using UV-vis spectroscophotometer (multiskan Go; Thermo Fisher Scientific, Inc.).

Next, to assess the ICG loading content, the optical absorption of conjugated ICG was measured by comparing absorption data at $780 \mathrm{~nm}$ before and after ICG conjugation onto the $\mathrm{Fe}_{3} \mathrm{O}_{4} @$ PEI-FPBA MNPs under a UV-vis spectrometer. The ICG loading content was calculated based on the calibration curve of ICG concentration at $780 \mathrm{~nm}$ (44). The loading content and efficiency of TMZ and ICG molecules onto the $\mathrm{Fe}_{3} \mathrm{O}_{4}$ MNPs were calculated as follows (45):

$$
\begin{gathered}
\text { Drug loading content }=\frac{\text { Amount of loaded TMZ (or ICG) }}{\text { Amount of TMZ (or ICG) loaded MNPs }} \times 100 \% \\
\text { Drug loading efficiency }=\frac{\text { Amount of loaded TMZ (or ICG) }}{\text { Total amount of TMZ (or ICG) initially added }} \times 100 \%
\end{gathered}
$$

Particle size distribution and morphology of MNPs. The particle size and morphology were determined with a high-resolution transmission electron microscope (HR-TEM; JEM 2010; JEOL Ltd.). The mean size of $\mathrm{Fe}_{3} \mathrm{O}_{4}$ MNPs was measured by TEM operating at $200 \mathrm{kV} \mathrm{FE}$ (Field Emmision) with $1.43 \AA$ resolution and their particle distribution were calculated by measuring the diameter of $~ 80$ nanoparticles using image analysis software (ImageJ 1.52a; National Institutes of Health). The average hydrodynamic size of TMZ and ICG-functionalized $\mathrm{Fe}_{3} \mathrm{O}_{4} @$ PEI-FPBA ( $\mathrm{Fe}_{3} \mathrm{O}_{4}$-TMZ-ICG) MNPs were determined by a dynamic light scattering (DLS) analyzer (LS 13320; Beckman Coulter, Inc.) in cell media. The average size of nanoparticles was calculated by Gaussian histogram curve fitting.

Analysis of NIR photothermal heating effects. To investigate the photothermal effect of free ICG, $\mathrm{Fe}_{3} \mathrm{O}_{4}$ only, $\mathrm{Fe}_{3} \mathrm{O}_{4}$-ICG and $\mathrm{Fe}_{3} \mathrm{O}_{4}$-TMZ-ICG aqueous suspension with two different $\mathrm{Fe}_{3} \mathrm{O}_{4}$ concentrations $(0,125$ and $250 \mu \mathrm{g} \mathrm{Fe} / \mathrm{ml})$ in water $(1 \mathrm{ml})$, was irradiated with 808-nm NIR laser (Changchun New Industries Optoelectronics Technology), at a power density of $1 \mathrm{~W} / \mathrm{cm}^{2}$ for $10 \mathrm{~min}$. The output power was adjusted by the measurement of a handy optical power meter (PMKIT-22-01; Newport Corporation). The temperature of the sample was detected using a thermal camera (FLIR i5; FLIR Systems, Inc.) above a sample holder as a function of irradiated NIR-light for the heat conversion effect.

Cell culture. U-87 MG, the human glioblastoma cell line was obtained from Korea cell line bank (cat. no. 30014). The U-87 MG cell line distributed by most cell collections (including the American Type Culture Collection, CLS and ECACC) is not the original glioblastoma cell line established in 1968 at the University of Uppsala, but the gene expression profile generated by the ATCC authentication indicates that this cell line is most probably also a glioblastoma cell line but whose origin is unknown (46). To ensure a human cell line for research, the STR profile of U-87 MG KCLB cell line was authenticated by comparing an STR profile of U-87 MG ATCC using the ATCC database. STR markers of U-87 MG KCLB cell line were identical to those of the accession no. CVCL-0022 of the U-87 MG ATCC cell line. Thus, the U-87 MG KCLB cell line was used as a cell model of a glioblastoma human cell line in this study.

The cells were cultured in a monolayer in Dulbecco's modified Eagle's medium (Thermo Fisher Scientific, Inc.), which was supplemented with $10 \%$ fetal bovine serum (Thermo Fisher Scientific, Inc.) and $1 \%(\mathrm{v} / \mathrm{v})$ penicillin-streptomycin (Thermo Fisher Scientific, Inc.). The cultured cells were incubated at $37^{\circ} \mathrm{C}$ in $5 \% \mathrm{CO}_{2}$, and the cell growth medium was replaced every 2 days. When the cells reached $80 \%$ confluence, the cells were harvested with $0.025 \%$ trypsin-EDTA solution.

Sample treatment and cancer photothermal therapy. For the photothermal therapy, U-87 MG cells were seeded at a density of $2 \times 10^{5}$ cells/well in a 24 well plate with $1 \mathrm{ml}$ of cell medium and incubated for $24 \mathrm{~h}$ at $37^{\circ} \mathrm{C}$. The cells were treated with different samples for $2 \mathrm{~h}$ prior to exposure of NIR laser irradiation followed by incubation for 2 or $22 \mathrm{~h}$. The cells without any treatment were used as a control. Both $\mathrm{Fe}_{3} \mathrm{O}_{4} \mathrm{MNPs}$ and ICG were utilized as NIR light absorbers to efficiently convert optical energy into thermal energy (47). To deliver the optimal thermal energy to cancer cells, the concentration of ICG-entrapped $\mathrm{Fe}_{3} \mathrm{O}_{4}$ MNPs $\left(\mathrm{Fe}_{3} \mathrm{O}_{4}\right.$-ICG-TMZ) was set to temperature in the range of $42-45^{\circ} \mathrm{C}$ under $808 \mathrm{~nm}$ of laser at a power density $1 \mathrm{~W} / \mathrm{cm}^{2}$ for $5 \mathrm{~min}$. The amount of $\mathrm{Fe}_{3} \mathrm{O}_{4}$ was equivalent in the $\mathrm{Fe}_{3} \mathrm{O}_{4}, \mathrm{Fe}_{3} \mathrm{O}_{4}$-ICG, and $\mathrm{Fe}_{3} \mathrm{O}_{4}$-ICG-TMZ MNPs samples $(125 \mu \mathrm{g} \mathrm{Fe} / \mathrm{ml})$, and the amount of ICG was equivalent in the free ICG and $\mathrm{Fe}_{3} \mathrm{O}_{4}$-ICG-TMZ MNPs samples $(3.1 \mu \mathrm{g} / \mathrm{ml})$. To investigate synergistic chemo-photothermal therapy, the concentration of free TMZ was set to the amount of 
TMZ corresponding concentration in $\mathrm{Fe}_{3} \mathrm{O}_{4}$-ICG-TMZ MNPs $(6.6 \mu \mathrm{g} / \mathrm{ml})$. The temperatures of cell mediums were monitored with a thermal camera during photothermal therapy.

Morphological changes and cell viability. To investigate photothermal effect to U-87 MG cells in vitro, the cells were seeded at a density of $2 \times 10^{5}$ cells/well in a 24 -well plate with $1 \mathrm{ml}$ cell medium and incubated for $24 \mathrm{~h}$ at $37^{\circ} \mathrm{C}$. The cells were incubated with $125 \mu \mathrm{g} \mathrm{Fe} / \mathrm{ml}$ of $\mathrm{Fe}_{3} \mathrm{O}_{4}, \mathrm{Fe}_{3} \mathrm{O}_{4}$-ICG and $\mathrm{Fe}_{3} \mathrm{O}_{4}$-TMZ-ICG MNPs, and equivalent free ICG and TMZ concentration, corresponding to $\mathrm{Fe}_{3} \mathrm{O}_{4}$-TMZ-ICG MNPs for $2 \mathrm{~h}$. The cells were treated with 808-nm NIR laser irradiation at $1 \mathrm{~W} / \mathrm{cm}^{2}$ for $5 \mathrm{~min}$ followed by incubation for $2 \mathrm{~h}$. Morphological changes of cells were observed under a bright field of optical microscope at x400 magnification (DMI300B; Leica Microsystems $\mathrm{GmbH}$ ) and digital images were captured at least three different sites for each sample.

Next, to evaluate photothermal effect on cell viability, cell viability was detected using WST-1 cell viability assay kit (EZ-CyTox; Daeil Lab Inc.) according to the manufacturer's protocols. The cells were seeded at a density of $1 \times 10^{4}$ cells/well in 96-well plates and incubated for $2 \mathrm{~h}$ at $37^{\circ} \mathrm{C}$. The cells were treated with various samples with or without laser irradiation. After $2 \mathrm{~h}$ incubation, the absorbance was measured at $450 \mathrm{~nm}$ using a microplate reader (Multiskan Go; Thermo Fisher Scientific, Inc.).

ROS generation and cell apoptosis. To confirm apoptosis induced by ROS generation, the cells were treated with samples and laser irradiation for $2 \mathrm{~h}$. After $2 \mathrm{~h}$ further incubation at $37^{\circ} \mathrm{C}$, the cell medium was removed and the cells incubated in a final concentration of $10 \mu \mathrm{M}$ dichloro-dihydro-fluorescein diacetate (DCFH-DA; Sigma-Aldrich; Merck KGaA) for $30 \mathrm{~min}$ at $37^{\circ} \mathrm{C}$. Cells were washed with PBS once, and ROS production was monitored under a fluorescence microscope at x200 magnification (Leica DMI300B; Leica Microsystems $\mathrm{GmbH}$ ). Digital images were captured at least three different sites for each sample. After DCFH-DA was converted to DCF by esterase, DCF exhibited green fluorescence when combined with ROS. As a result, the DCF green intensity signifies the levels of ROS generation (48), indicative of the apoptotic cell pathway (49).

Live/dead cell assay. After $22 \mathrm{~h}$ incubation at $37^{\circ} \mathrm{C}$ with sample and laser therapy, to evaluate cytotoxic effect in vitro during photothermal therapy, a live/dead cell assay was conducted using a calcein-AM/propidium iodide (PI) double staining kit (Sigma-Aldrich; Merck KGaA) according to the manufacturer's instructions. U-87 MG cells stained with calcein-AM/PI were simultaneous imaged soon after staining under a fluorescence microscope at x200 magnification. Digital images were captured at least three different sites for each sample. A calcein-AM/PI double kit is used for a two-color fluorescence cell viability assay that is based on the simultaneous fluorescence staining of live and dead cells. Calcein-AM a non-fluorescent cell-permeable ester that can passively penetrate viable cells with intact plasma membranes. The calcein generated from calcein-AM by esterase in a viable cell emits a green fluorescence (50). Conversely, PI cannot pass through an intact cell membrane. PI enters cells with compromised cell membranes and disordered areas of dead cell membrane, and intercalates with the DNA double helix of the cell to emit red fluorescence $(51,52)$. Therefore, green and red fluorescent cells indicate live and dead cells, respectively (53). Calcein-AM and PI fluorescent intensities were quantified using standard imaging software (ImageJ software), and the results were expressed as integrated density based on green and red fluorescence in each image.

Confocal microscopy analysis. To investigate the photothermal-induced cellular damage, cell membrane disruption was observed under a confocal microscope (LSM 700; Zeiss $\mathrm{GmbH})$. After cell treatment, the cells were washed twice with cold PBS and fixed with cold $3.7 \%$ formaldehyde for $20 \mathrm{~min}$ at room temperature. Furthermore, to investigate internalized $\mathrm{Fe}_{3} \mathrm{O}_{4}$-TMZ-ICG MNPs into the nucleus in the U-87 MG cells upon NIR laser irradiation, cellular uptake of $\mathrm{Fe}_{3} \mathrm{O}_{4}$-TMZ-ICG MNPs was monitored using a confocal microscope at $\mathrm{x} 40$ magnification.

Flow cytometric analysis. To quantify in vitro cell cytotoxicity, flow cytometry was conducted. The cell population of live/apoptotic cells were analyzed using an Annexin V-FITC Apoptosis Detection Kit (BD Pharmingen ${ }^{\mathrm{TM}}$; BD Biosciences) according to the manufacturer's protocol by flow cytometry (BD FACSVerse; BD Biosciences). After $22 \mathrm{~h}$ incubation at $37^{\circ} \mathrm{C}$, floating and attached cells in the medium were collected by trypsinization. After collecting $5 \times 10^{5}$ cells by centrifugation at $600 \mathrm{x} \mathrm{g}$ for $1 \mathrm{~min}$ at $37^{\circ} \mathrm{C}$, cells were re-suspended in $100 \mu \mathrm{l}$ of $1 \mathrm{X}$ binding buffer. The cell suspension was incubated with $10 \mu \mathrm{g} / \mathrm{ml}$ of Annexin V-FITC/PI double staining solution for $15 \mathrm{~min}$ at room temperature in the dark. An additional $400 \mu \mathrm{l}$ $1 \mathrm{X}$ binding buffer was added to cell suspension, and then the fluorescence of cells was immediately analyzed with a flow cytometer.

Western blot analysis. After treatment for $24 \mathrm{~h}$ at $37^{\circ} \mathrm{C}$, the cells were washed twice with PBS, and lysed using a radioimmunoprecipitation assay buffer (Sigma-Aldrich; Merck KGaA) containing protease inhibitor (Roche Applied Science). Cytosolic and mitochondrial fractions for cytochrome $c$ detection were isolated using a mitochondria isolation kit (Abcam) according to the manufacturer's instructions. The protein concentration was determined using a Pierce ${ }^{\circledR}$ BCA protein assay kit (Thermo Fisher Scientific, Inc.). Total protein $(25 \mu \mathrm{g})$ was separated using 10\% SDS-PAGE and then transferred to a nitrocellulose membrane. After blocking three times at each 5 min interval with 5\% skim milk in TBS-T (Tris-buffered saline containing $0.1 \%$ Tween-20) at room temperature, the membrane was reacted with $\mathrm{Bcl}-2$-associated $\mathrm{X}$ protein (Bax; cat. no. sc-20067, 1:200; Santa Cruz Biotechnology, Inc.), Bcl-2 (cat. no. sc-23960, 1:200; Santa Cruz Biotechnology, Inc.), cytochrome $c$ (cat. no. sc-13561, 1:200; Santa Cruz Biotechnology, Inc.), caspase-3 (cat. no. sc-271759, 1:200; Santa Cruz Biotechnology, Inc.), cleaved caspase-3 (cat. no. 9661, 1:1,000; Cell Signaling Technology,Inc.), $\beta$-actin antibody (cat. no. sc-47778, 1:500; Santa Cruz Biotechnology, Inc.), or cytochrome $c$ oxidase (COX IV; cat. no. sc-376731, 1:500; Santa Cruz Biotechnology, Inc.) overnight at $4^{\circ} \mathrm{C}$. The membrane was washed three times with TBS-T, 5 min each 

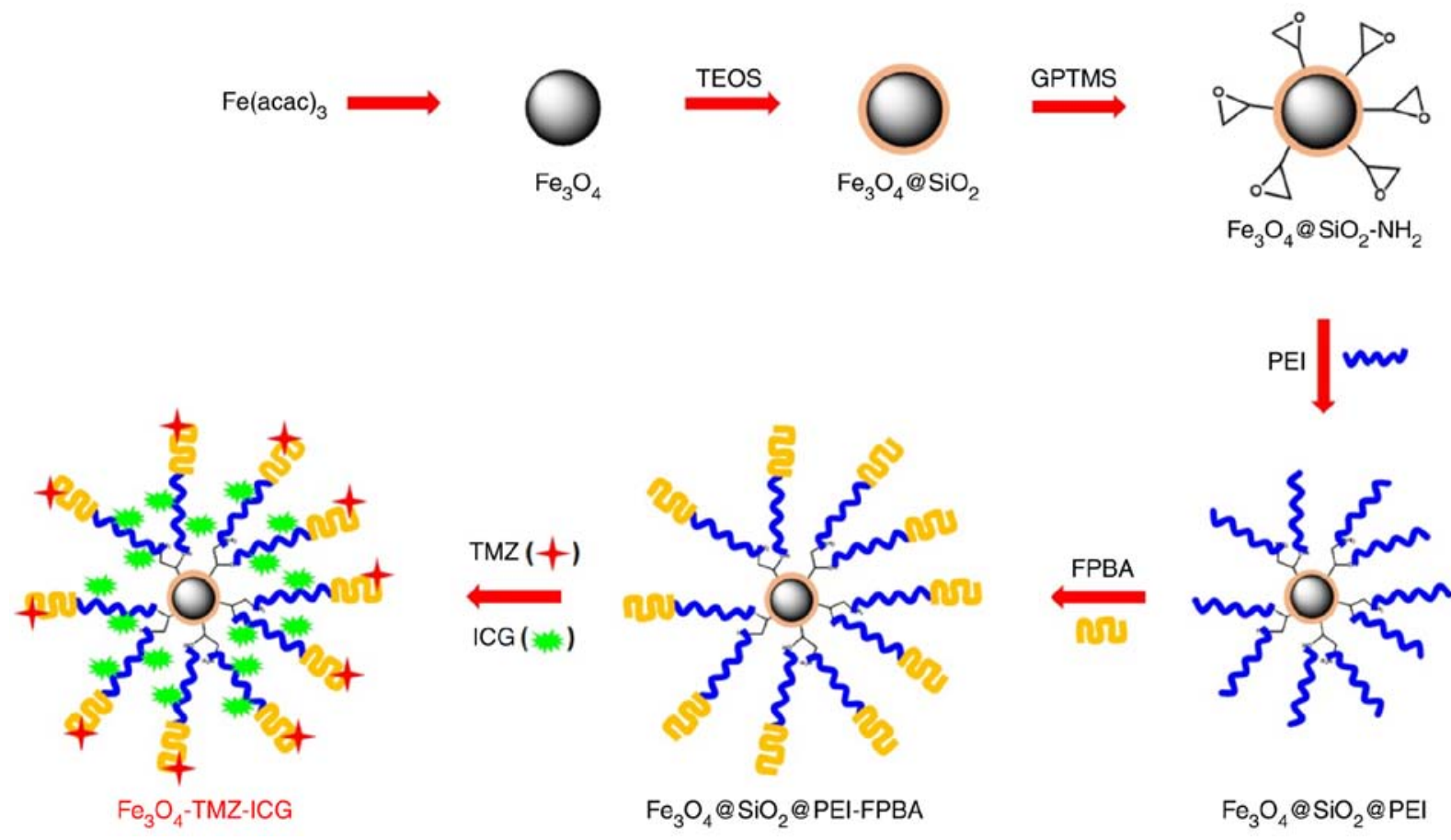

Figure 1. Schematic diagram of $\mathrm{Fe}_{3} \mathrm{O}_{4}$ MNPs synthesis, and the formation process of ICG- and TMZ-entrapped multimodal Fe $\mathrm{O}_{4}$ MNPs. FPBA, formylphenylboronic acid; GPTMS, 3-glycidyloxypropyl trimethoxysilane; ICG, indocyanine green; MNPs, magnetic nanoparticles; PEI, polyethylenimine; TEOS, tetraethyl orthoslicate; TMZ, temozolomide.

followed by incubation for $2 \mathrm{~h}$ with mouse $\operatorname{IgG} \kappa$ binding protein $(\mathrm{m}-\mathrm{IgG \kappa} \mathrm{BP})$ conjugated to horseradish peroxidase (cat. no. sc-516102, 1:1,000; Santa Cruz Biotechnology, Inc.), or anti-rabbit IgG, HRP-linked secondary antibody (cat. no. 7074, 1:1,000; Cell Signaling Technology, Inc.) at room temperature. $\beta$-actin and COX IV were used as loading controls for whole cell and cytosolic proteins, and mitochondrial proteins, respectively.

After washing three times with TBS-T for $5 \mathrm{~min}$, the bands were developed using an ECL Western Blotting Detection Kit Reagent (Thermo Fisher Scientific, Inc.) and imaged on Davinch-Chemi $^{\mathrm{TM}}$ imaging system (CAS-400SM, Davinch-K). The relative band intensities of each target protein expression were quantitated using ImageJ software (version 1.52a), compared with the levels of the $\beta$-actin or COX IV protein expression as a reference.

Reverse transcription-quantitative polymerase chain reaction $(R T-q P C R)$. After treatment for $24 \mathrm{~h}$, Total RNA was isolated using a TRIzol ${ }^{\circledR}$ reagent (Thermo Fisher Scientific, Inc.) according to the manufacturer's instructions. Total RNA $(2 \mu \mathrm{g})$ was reverse-transcribed into cDNA using a cDNA synthesis kit (ET21025; PhileKorea) under the following conditions: Incubation at $42^{\circ} \mathrm{C}$ for $30 \mathrm{~min}$ and denaturation $70^{\circ} \mathrm{C}$ for $10 \mathrm{~min}$. For qPCR, primers were designed using Prime-BLAST (https://www.ncbi.nlm.nih.gov/tools/primer-blast/) and commercially obtained from Mbiotech Inc. The reaction was amplified with QunatiSpeed SYBR ${ }^{\circledR}$ No-Rox Kit (PhileKorea) using primers (GAPDH, forward, 5'-AGAGGCAGGGAT GTTCTG-3' and reverse, 5'-GACTCATGACCACAGTCC ATGC-3'; Fas associated via death domain (FADD), forward, 5'-CCGCCATCCTTCACCAGA-3' and reverse, 5'-CAATCA CTCATCAGC-3'; caspase-8, forward, 5'-CCTCATCAATCG
GCTGGAC-3' and reverse, 5'-ATGACCCTGTAGGCAGAA ACC-3'). The quantification cycle $(\mathrm{Cq})$ values were obtained via $\mathrm{qPCR}$ with a Magnetic Induction Cycler (Bio Molecular Systems). Transcription levels of every gene were normalized to the levels of GADH. qPCR was performed under the following conditions: Pre-denaturation at $95^{\circ} \mathrm{C}$ for $5 \mathrm{~min}$, denaturation at $90^{\circ} \mathrm{C}$ for $30 \mathrm{sec}$, annealing at $60^{\circ} \mathrm{C}$ for $40 \mathrm{sec}$ and extension at $72^{\circ} \mathrm{C}$ for $40 \mathrm{sec}$, for a total of 40 cycles. GAPDH was used as a reference gene and the relative fold change values were calculated by normalization to GAPDH expression via the $2^{-\Delta \Delta \mathrm{Cq}}$ method (54).

Relative mRNA expression, $\Delta \Delta \mathrm{Cq}=2^{-\Delta \Delta \mathrm{Cq}}$, where, $\Delta \Delta \mathrm{Cq}=\Delta \mathrm{Cq}$ (a target gene) $-\Delta \mathrm{Cq}$ (a reference gene).

Statistical analysis. All statistics analyses were performed with Sigma Plot 12.0 (Systat Software Inc., San Jose, CA, USA). The levels of significance were calculated using a one-way ANOVA for comparisons with the control group. The experiments for each sample were repeated at least three times. Data are presented as the mean \pm standard deviation. $\mathrm{P}<0.05$ was considered to indicate a statistically significant difference.

\section{Results and discussion}

Characterization of $\mathrm{Fe}_{3} \mathrm{O}_{4}-\mathrm{TMZ}-\mathrm{ICG} M N P S$. The synthesis process of biocompatible $\mathrm{Fe}_{3} \mathrm{O}_{4}$-TMZ-ICG MNPs as chemo-photothermal therapeutic agents is presented in Fig. 1. The crystal structure of synthesized $\mathrm{Fe}_{3} \mathrm{O}_{4}$ MNPs was analyzed by XRD pattern (Fig. 2A). The distinctive intensities of (220), (311), (400), (422), (511) and (440) peaks at 2q=30.05, 35.39, $43.01,53.36,65.67$ and $66.72^{\circ}$, which corresponded to inverse spinel structure of $\mathrm{Fe}_{3} \mathrm{O}_{4}$ (JCPDS 85-1436), were observed in the pristine $\mathrm{Fe}_{3} \mathrm{O}_{4}$ MNPs with well-defined crystallinity. After 

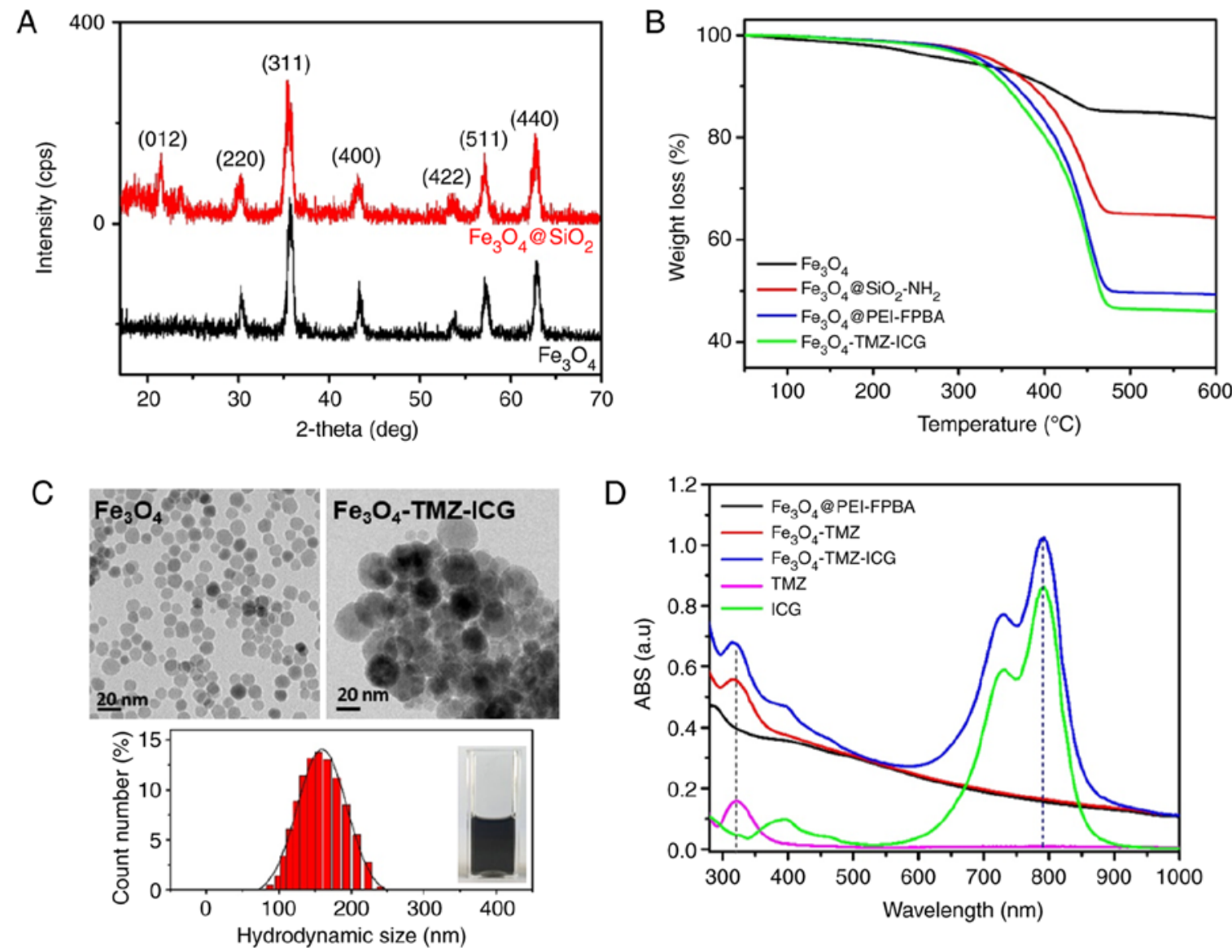

Figure 2. Characterizations of physicochemical properties. (A) X-ray diffraction patterns of inorganic $\mathrm{Fe}_{3} \mathrm{O}_{4}$ and $\mathrm{Fe}_{3} \mathrm{O}_{4} @ \mathrm{SiO}_{2} \mathrm{MNPs}$. (B) Thermal gravimetric analysis curves of $\mathrm{Fe}_{3} \mathrm{O}_{4}$ MNPs, $\mathrm{SiO}_{2}-\mathrm{NH}_{2}$, PEI-FPBA, and TMZ-ICG-coated $\mathrm{Fe}_{3} \mathrm{O}_{4}$ MNPs. (C) High-resolution transmission electron microscopy images of $\mathrm{Fe}_{3} \mathrm{O}_{4}$ and $\mathrm{Fe}_{3} \mathrm{O}_{4}$-TMZ-ICG MNPs, and the average hydrodynamic diameter of $\mathrm{Fe}_{3} \mathrm{O}_{4}$-TMZ-ICG MNPs in aqueous solution by dynamic light scattering measurement (inset; $\mathrm{Fe}_{3} \mathrm{O}_{4}$-TMZ-ICG MNPs aqueous dispersion). (D) Changes in UV-vis spectra before and after TMZ and ICG loading onto Fe $\mathrm{O}_{4} \mathrm{MNPs}$ ABS, absorbance; FPBA, formylphenylboronic acid; ICG, indocyanine green; MNPs, magnetic nanoparticles; PEI, polyethylenimine; TMZ, temozolomide.

silica coating, the obtained $\mathrm{Fe}_{3} \mathrm{O}_{4} @ \mathrm{SiO}_{2}$ MNPs in the crystalline structure showed the characteristic peaks of $\mathrm{Fe}_{3} \mathrm{O}_{4}$ MNPs and the additional broad peak of amorphous $\mathrm{SiO}_{2}$ coating shell indexed as (012), which was observed at $20-30^{\circ}$. The intrinsic peaks of $\mathrm{Fe}_{3} \mathrm{O}_{4}$ MNPs were well-preserved during the process of functionalization with $\mathrm{SiO}_{2}$.

The content of functional shells on the $\mathrm{Fe}_{3} \mathrm{O}_{4}$ MNPs were estimated by TGA (Fig. 2B). Weight reductions indicate the content of organic materials on the functionalized $\mathrm{Fe}_{3} \mathrm{O}_{4}$ MNPs. The decrease in weight at temperatures $<200^{\circ} \mathrm{C}$ indicated the removal of residual adsorbed solvent in the MNPs, and that at temperatures $>250^{\circ} \mathrm{C}$ was attributed to organic materials. The weight of each sample gradually decreased at $>450^{\circ} \mathrm{C}$ under $\mathrm{N}_{2}$ atmosphere. The TGA thermogram of $\mathrm{Fe}_{3} \mathrm{O}_{4}$ MNPs showed a constant weight reduction with increasing temperature as of the removal of free oleic acid and decomposition of oleic acid bound to $\mathrm{Fe}_{3} \mathrm{O}_{4} \mathrm{MNPs}$. The $\mathrm{Fe}_{3} \mathrm{O}_{4} @ \mathrm{SiO}_{2} \mathrm{MNPs}$ showed notable weight loss, of $\sim 35.95 \%$ at $250-450^{\circ} \mathrm{C}$, mainly due to the decomposition of coated $\mathrm{SiO}_{2}-\mathrm{NH}_{2}$ on the $\mathrm{Fe}_{3} \mathrm{O}_{4}$ MNPs surface. The PEI-FPBA encapsulated $\mathrm{Fe}_{3} \mathrm{O}_{4}$ MNPs exhibited increased weight reductions of $\sim 51.31 \%$ than $\mathrm{Fe}_{3} \mathrm{O}_{4}$ and $\mathrm{Fe}_{3} \mathrm{O}_{4} @ \mathrm{SiO}_{2}-\mathrm{NH}_{2} \mathrm{MNPs}$ due to the decomposition of coated PEI and FPBA on the $\mathrm{Fe}_{3} \mathrm{O}_{4}$ MNPs surface. At a temperature of $500^{\circ} \mathrm{C}$, the functional shells on the $\mathrm{Fe}_{3} \mathrm{O}_{4}$ MNPs decomposed by $\sim 100 \%$. Using TGA thermogram analysis, final residual naked $\mathrm{Fe}_{3} \mathrm{O}_{4}$ weights with high thermal stability were determined to be 83.89, 64.32, 49.31, and $45.89 \%$ for $\mathrm{Fe}_{3} \mathrm{O}_{4}$, $\mathrm{Fe}_{3} \mathrm{O}_{4} @ \mathrm{SiO}_{2}-\mathrm{NH}_{2}, \mathrm{Fe}_{3} \mathrm{O}_{4} @$ PEI-FPBA, and $\mathrm{Fe}_{3} \mathrm{O}_{4}$-TMZ-ICG MNPs, respectively. Calculations revealed that the $\mathrm{Fe}_{3} \mathrm{O}_{4}$ content of $\mathrm{Fe}_{3} \mathrm{O}_{4}$-TMZ-ICG MNPs could be $\leq 45.89 \mathrm{wt} \%$.

The average size and morphology of $\mathrm{Fe}_{3} \mathrm{O}_{4}$ and modified $\mathrm{Fe}_{3} \mathrm{O}_{4}$-TMZ-ICG MNPs were observed by HR-TEM images (Fig. 2C). The $\mathrm{Fe}_{3} \mathrm{O}_{4}$ cores were monodispersed and spherical in shape, and showed uniform particle size with an average size of $\sim 13 \mathrm{~nm}$. The average hydrodynamic size of $\mathrm{Fe}_{3} \mathrm{O}_{4}$-TMZ-ICG MNPs measured by DLS was $159.52 \pm 34.15 \mathrm{~nm}$ in aqueous dispersion. The $\mathrm{Fe}_{3} \mathrm{O}_{4}$-TMZ-ICG MNPs showed good colloidal stability without any considerable aggregation (Fig. $2 \mathrm{C}$ inset).

Determination of TMZ- and ICG-loading contents. UV-vis spectroscopy was employed in order to confirm the successful TMZ- and ICG-loading onto the $\mathrm{Fe}_{3} \mathrm{O}_{4} @$ PEI-FPBA MNPs (Fig. 2D). The $\mathrm{Fe}_{3} \mathrm{O}_{4}$-TMZ-ICG MNPs with maximum absorption at 328 and $780 \mathrm{~nm}$ revealed the presence of the condensation of TMZ and electrostatic interaction of ICG with $\mathrm{Fe}_{3} \mathrm{O}_{4} @$ PEI-FPBA MNPs, which could be used to quantify the TMZ and ICG concentration. TMZ- and ICG-loading contents in $\mathrm{Fe}_{3} \mathrm{O}_{4}$-TMZ-ICG MNPs was determined by the difference of optical absorbance at 328 and $780 \mathrm{~nm}$, respectively, after subtracting the optical absorbance of $\mathrm{Fe}_{3} \mathrm{O}_{4} @$ PEI-FPBA 

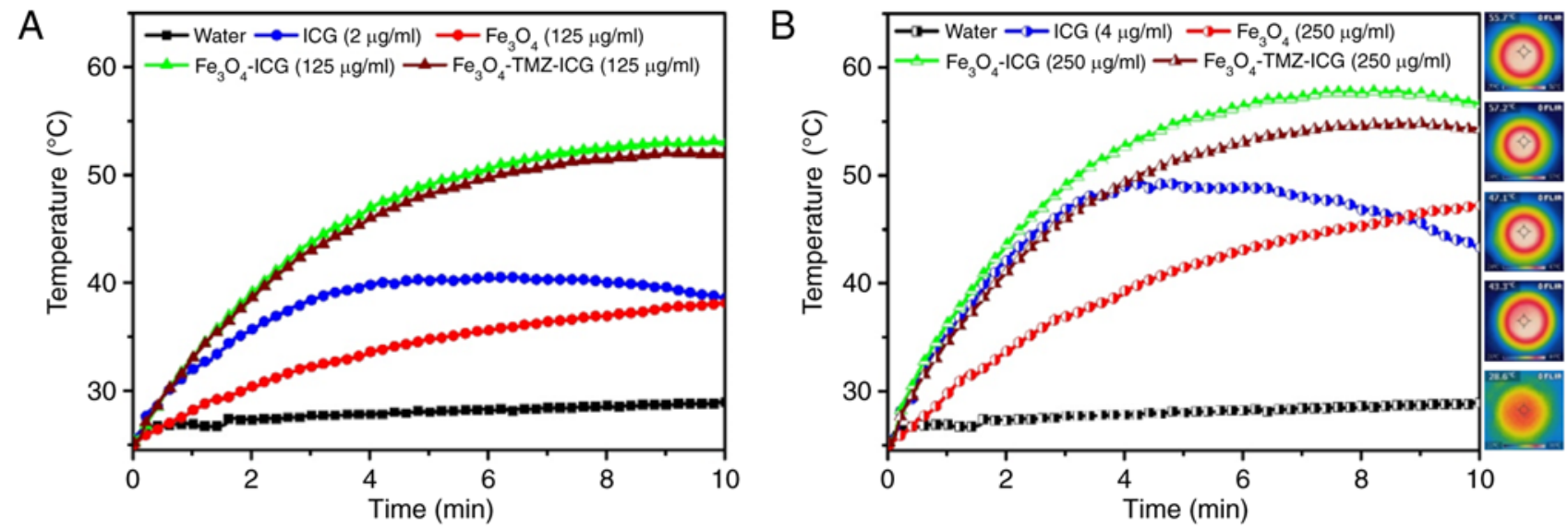

Figure 3. Photothermally induced thermal responses of $\mathrm{Fe}_{3} \mathrm{O}_{4}$-TMZ-ICG magnetic nanoparticles. (A) Temperature elevation curves with $2 \mu \mathrm{g} / \mathrm{ml}$ free ICG, and $125 \mu \mathrm{g} \mathrm{Fe} / \mathrm{ml}$ of $\mathrm{Fe}_{3} \mathrm{O}_{4}, \mathrm{Fe}_{3} \mathrm{O}_{4}$-ICG, and $\mathrm{Fe}_{3} \mathrm{O}_{4}$-TMZ-ICG aqueous solution. (B) Temperature elevation curves (left), and thermal camera images (right) of $4 \mu \mathrm{g} / \mathrm{ml}$ free ICG $(2 \mu \mathrm{g} / \mathrm{ml})$, and $250 \mu \mathrm{g} \mathrm{Fe} / \mathrm{ml}$ of $\mathrm{Fe}_{3} \mathrm{O}_{4}, \mathrm{Fe}_{3} \mathrm{O}_{4}-\mathrm{ICG}$, and $\mathrm{Fe}_{3} \mathrm{O}_{4}$-TMZ-ICG aqueous solution. Sample solution (1 ml) was transferred into a 24 well plate and compared as a function of sample concentration under $808 \mathrm{~nm}$ near-infrared laser irradiation at $1 \mathrm{~W} / \mathrm{cm}^{2}$ for 10 min. ICG, indocyanine green; TMZ, temozolomide.

MNPs before TMZ- and ICG-molecules loading. Based on the optical absorbance of TMZ- and ICG-molecules and the linear calibration curves of TMZ- and ICG-concentration at 328 and $780 \mathrm{~nm}$, respectively, TMZ- and ICG-loading contents were $\sim 26.4$ and $12.4 \mu \mathrm{g}$ per $1.5 \mathrm{mg} / \mathrm{ml}$ of $\mathrm{Fe}_{3} \mathrm{O}_{4}$-TMZ-ICG aqueous solution. MNPs, and the loading efficiencies of TMZ and ICG were respectively found to be 35.2 and $21.4 \%$. The calculated TMZ- and ICG-loading contents were determined to be $\sim 6.6$ and $3.1 \mu \mathrm{g}$ per $173 \mathrm{mg}$ of $\mathrm{Fe}_{3} \mathrm{O}_{4} \mathrm{MNPs}(125 \mu \mathrm{g} \mathrm{Fe} / \mathrm{ml})$. The $\mathrm{Fe}_{3} \mathrm{O}_{4}$-TMZ-ICG MNPs showed high optical absorption in the NIR region with a high drug loading efficiency of $\leq 50 \%$, suggesting that the $\mathrm{Fe}_{3} \mathrm{O}_{4}$-TMZ-ICG MNPs can be applied in synergistic chemo-photothermal therapy under NIR laser irradiation.

Photothermal performance of $\mathrm{Fe}_{3} \mathrm{O}_{4}$-TMZ-ICG MNPs. The photothermal heating responses of free ICG, $\mathrm{Fe}_{3} \mathrm{O}_{4}$ only, $\mathrm{Fe}_{3} \mathrm{O}_{4}$-ICG, and $\mathrm{Fe}_{3} \mathrm{O}_{4}$-TMZ-ICG MNPs were examined with the different concentrations in water $(1 \mathrm{ml})$ for $10 \mathrm{~min}$ with 808-nm NIR laser irradiation at $1 \mathrm{~W} / \mathrm{cm}^{2}$. As shown Fig. 3, the temperature of $\mathrm{Fe}_{3} \mathrm{O}_{4}$ solution upon 808-nm NIR laser irradiation was increased with the increase of $\mathrm{Fe}_{3} \mathrm{O}_{4}$ concentration and laser exposure time $\left(\Delta \mathrm{T}=9.8^{\circ} \mathrm{C}\right.$ at $125 \mu \mathrm{g} \mathrm{Fe} / \mathrm{ml}$ and $\Delta \mathrm{T}=16.58^{\circ} \mathrm{C}$ at $250 \mu \mathrm{g} \mathrm{Fe} / \mathrm{ml}$ for $5 \mathrm{~min}$, and $\Delta \mathrm{T}=13.1^{\circ} \mathrm{C}$ at $125 \mu \mathrm{g} \mathrm{Fe} / \mathrm{ml}$ and $\Delta \mathrm{T}=22.2^{\circ} \mathrm{C}$ at $250 \mu \mathrm{g} \mathrm{Fe} / \mathrm{ml}$ for $10 \mathrm{~min}$ ), whereas the temperature of pure water showed no notable change. On the contrary, the temperature of free ICG solution quickly increased at the initial $4 \mathrm{~min}$ of exposure to $808-\mathrm{nm}$ NIR laser irradiation, followed by the gradual decrease due to photo-degradation of ICG (55). ICG- and $\mathrm{Fe}_{3} \mathrm{O}_{4}$-conjugated MNPs $\left(\mathrm{Fe}_{3} \mathrm{O}_{4}\right.$-ICG and $\mathrm{Fe}_{3} \mathrm{O}_{4}$-TMZ-ICG) exhibited higher heating efficiency with the sample concentration and laser exposure time $\left(\Delta \mathrm{T}=23.8^{\circ} \mathrm{C}\right.$ at $125 \mu \mathrm{g} \mathrm{Fe} / \mathrm{ml}$ and $\Delta \mathrm{T}=29.8^{\circ} \mathrm{C}$ at $250 \mu \mathrm{g} \mathrm{Fe} / \mathrm{ml}$ for $5 \mathrm{~min}$, and $\Delta \mathrm{T}=27.7^{\circ} \mathrm{C}$ at $125 \mu \mathrm{g} \mathrm{Fe} / \mathrm{ml}$ and $\Delta \mathrm{T}=31.3^{\circ} \mathrm{C}$ at $250 \mu \mathrm{g} \mathrm{Fe} / \mathrm{ml}$ for $10 \mathrm{~min}$ for $\mathrm{Fe}_{3} \mathrm{O}_{4}$-ICG; $\Delta \mathrm{T}=23.1^{\circ} \mathrm{C}$ at $125 \mu \mathrm{g} \mathrm{Fe} / \mathrm{ml}$ and $\Delta \mathrm{T}=26.5^{\circ} \mathrm{C}$ at $250 \mu \mathrm{g} \mathrm{Fe} / \mathrm{ml}$ for $5 \mathrm{~min}$, and $\Delta \mathrm{T}=26.8^{\circ} \mathrm{C}$ at $125 \mu \mathrm{g} \mathrm{Fe} / \mathrm{ml}$ and $\Delta \mathrm{T}=29.0^{\circ} \mathrm{C}$ at $250 \mu \mathrm{g} \mathrm{Fe} / \mathrm{ml}$ for $10 \mathrm{~min}$ for $\mathrm{Fe}_{3} \mathrm{O}_{4}$-TMZ-ICG) compared with the $\mathrm{Fe}_{3} \mathrm{O}_{4}$ MNPs and ICG alone. Of note, the photostability of ICG entrapped in $\mathrm{Fe}_{3} \mathrm{O}_{4}$ MNPs markedly improved due to the reduced intramolecular interactions within ICG (56).

Further, the corresponding IR thermal camera images of ICG, $\mathrm{Fe}_{3} \mathrm{O}_{4}, \mathrm{Fe}_{3} \mathrm{O}_{4}$-ICG, and $\mathrm{Fe}_{3} \mathrm{O}_{4}$-TMZ-ICG solution during 10 min of NIR laser irradiation revealed homogeneous distribution of temperature with fast heat dissipation. These results indicate that ICG-entrapped $\mathrm{Fe}_{3} \mathrm{O}_{4}$ MNPs could be an effective photothermal agent with high heating ability and thermal stability.

Detection of intracellular ROS generation by chemophotothermal therapy. ROS generation associated with cellular membrane damage was examined using ICGand/or TMZ-conjugated $\mathrm{Fe}_{3} \mathrm{O}_{4}$ MNPs with NIR laser irradiation (Fig. 4). Intracellular production of ROS can cause irreversible damage to target cancer cells and triggering of apoptosis (57). NIR laser stimuli can induce cellular damage by not only the thermal effect, but also via heat stress-induced ROS during photothermal therapy to target cancer cells (58). Furthermore, several anticancer drugs induce ROS generation via oxidative stress (59). Importantly, in this study, ICG was proposed to be effectively applied as a photothermal agent and photodynamic photosensitizer to generate heat and toxic ROS upon NIR laser irradiation for the ablation of cancer cells (60).

The intracellular ROS generation in U-87 MG cells treated without sample, or $3.1 \mu \mathrm{g} / \mathrm{ml} \mathrm{ICG,} 6.6 \mu \mathrm{g} / \mathrm{ml} \mathrm{TMZ}$, and $125 \mu \mathrm{g}$ $\mathrm{Fe} / \mathrm{ml} \mathrm{Fe}_{3} \mathrm{O}_{4}, \mathrm{Fe}_{3} \mathrm{O}_{4}$-ICG and $\mathrm{Fe}_{3} \mathrm{O}_{4}$-TMZ-ICG MNPs with or without $808-\mathrm{nm}$ NIR laser irradiation $\left(1 \mathrm{~W} / \mathrm{cm}^{2}, 5 \mathrm{~min}\right)$ after $2 \mathrm{~h}$ was confirmed by DCF green fluorescence stain under a fluorescence microscope. Without 808-nm NIR laser irradiation, all cells exhibited no considerable intracellular ROS production. In contrast, all cells treated with samples exhibited notable ROS production upon 808-nm NIR laser irradiation. In addition, as shown in Fig. 4I, the cells treated with TMZ- and ICG-loaded $\mathrm{Fe}_{3} \mathrm{O}_{4}\left(\mathrm{Fe}_{3} \mathrm{O}_{4}\right.$-TMZ-ICG) MNPs showed a strong green fluorescence intensity, which indicated considerably enhanced ROS production, along with higher cytotoxicity in cell morphology. ROS production was more strongly detected in the $\mathrm{Fe}_{3} \mathrm{O}_{4}$-TMZ-ICG MNPs-treated cells 

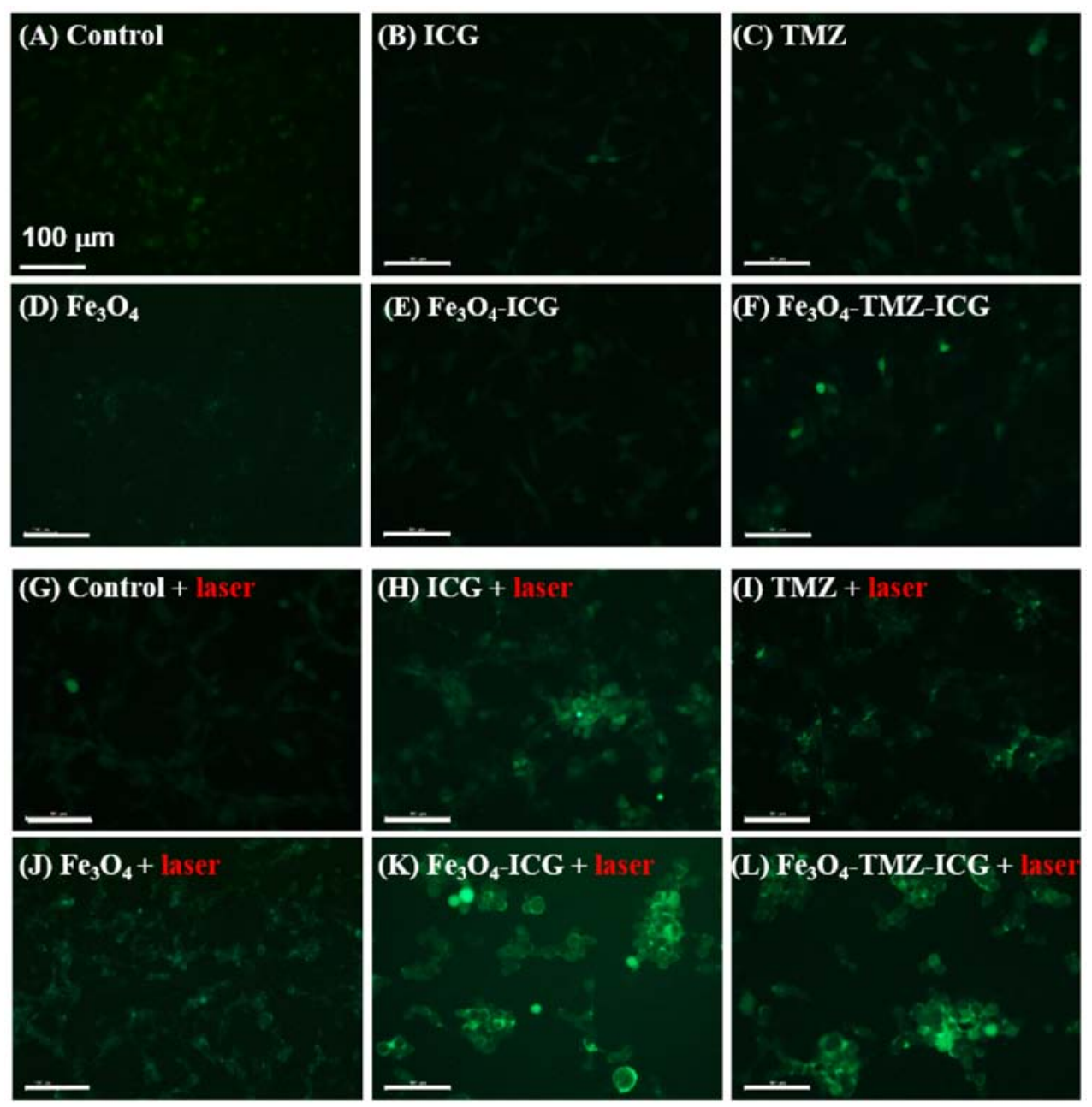

Figure 4. Intracellular reactive oxygen species detection under different conditions via fluorescence microscopy. U-87 MG cells were pre-treated with different samples (no sample, $3.1 \mu \mathrm{g} / \mathrm{ml} \mathrm{ICG}, 6.6 \mu \mathrm{g} / \mathrm{ml} \mathrm{TMZ}$, and $125 \mu \mathrm{g} \mathrm{Fe} / \mathrm{ml} \mathrm{Fe}_{3} \mathrm{O}_{4}, \mathrm{Fe}_{3} \mathrm{O}_{4}$-ICG and $\mathrm{Fe}_{3} \mathrm{O}_{4}$-TMZ-ICG magnetic nanoparticles) before near-infrared laser exposure. After $2 \mathrm{~h}$ incubation, the cells were treated with or without near-infrared laser irradiation for $5 \mathrm{~min}\left(1 \mathrm{~W} / \mathrm{cm}^{2}\right)$ followed by further incubation for $2 \mathrm{~h}$. Scale bar, $100 \mu \mathrm{m}$. ICG, indocyanine green; TMZ, temozolomide.

compared with the cells treated with ICG, TMZ, $\mathrm{Fe}_{3} \mathrm{OMNPs}$ or laser alone. Taken together, experimental results indicate that ROS production was synergistically enhanced by the combination of chemo-phototherapy using $\mathrm{Fe}_{3} \mathrm{O}_{4}$-TMZ-ICG MNPs.

Morphological changes and cell viability by chemophotothermal therapy. To evaluate the cytotoxic effect in combination with the chemotherapeutic and phototherapeutic treatments, the U-87 MG cells were incubated with the different samples $(3.1 \mu \mathrm{g} / \mathrm{ml} \mathrm{ICG}, 6.6 \mu \mathrm{g} / \mathrm{ml} \mathrm{TMZ}$, and $125 \mu \mathrm{g} \mathrm{Fe} / \mathrm{ml}$ of $\mathrm{Fe}_{3} \mathrm{O}_{4}, \mathrm{Fe}_{3} \mathrm{O}_{4}-\mathrm{ICG}$ and $\mathrm{Fe}_{3} \mathrm{O}_{4}-\mathrm{TMZ}-\mathrm{ICG}$ MNPs) for $2 \mathrm{~h}$, followed by 808-nm NIR laser irradiation at $1 \mathrm{~W} / \mathrm{cm}^{2}$ for $5 \mathrm{~min}$. The cells were further incubated for $22 \mathrm{~h}$, and then alterations in cell morphology were observed under an optical microscope (Fig. 5A). Both control cells and those treated with photothermal agents (ICG, $\mathrm{Fe}_{3} \mathrm{O}_{4}$ and $\mathrm{Fe}_{3} \mathrm{O}_{4}$-ICG MNPs) without 808-nm NIR laser treatment showed no marked morphological changes, suggesting that ICG, $\mathrm{Fe}_{3} \mathrm{O}_{4}$ only, and $\mathrm{Fe}_{3} \mathrm{O}_{4}$-ICG MNPs have high biocompatibility and low cytotoxicity in vitro (Fig. 5A). Cells treated with TMZ alone and TMZ-loaded $\mathrm{Fe}_{3} \mathrm{O}_{4}$-ICG MNPs as a chemo and chemo-photothermal agent without 808-nm NIR laser treatment (Fig. 5Ac and f), showed no considerable damage in cell morphology compared with control cells (Fig. 5Aa).

Conversely, with 808-nm NIR laser treatment, the cells treated with ICG, $\mathrm{Fe}_{3} \mathrm{O}_{4}$ and $\mathrm{Fe}_{3} \mathrm{O}_{4}$-ICG MNPs as photothermal agents showed notable cellular damage, such as cell shrinkage, nuclear condensation, and loss of cell volume (Fig. 5Ah, j and k), whereas the control showed no marked damage (Fig. 5Ag). In addition, the intracellular uptake of $\mathrm{Fe}_{3} \mathrm{O}_{4}$ MNPs into U-87 MG cells improved after NIR laser irradiation (Fig. 5Aj, $\mathrm{k}$ and $\mathrm{l}$ ). Next, for the cells treated with TMZ, a chemotherapeutic agent for brain cancer (61), with 808-nm NIR laser treatment, there was a slight reduction in cell viability (Fig. 5Ai). Finally, the cells treated with TMZ-loaded $\mathrm{Fe}_{3} \mathrm{O}_{4}$-ICG MNPs, a chemo-photothermal agent with 808-nm NIR laser treatment, showed notable cellular damage with a reduction in the cell population.

Next, the viability of ICG, TMZ, $\mathrm{Fe}_{3} \mathrm{O}_{4}$ alone, $\mathrm{Fe}_{3} \mathrm{O}_{4}$-ICG and $\mathrm{Fe}_{3} \mathrm{O}_{4}$-TMZ-ICG MNPs with or without NIR laser irradiation was measured in U-87 MG cells by WST-1 assay (Fig. 5B). Without NIR laser irradiation, all cells presented almost comparable cell viability compared with that of the control. With NIR laser irradiation, the cells treated with TMZ only showed small reductions in cell viability $(91.01 \%)$, whereas the control 
A (a) Control
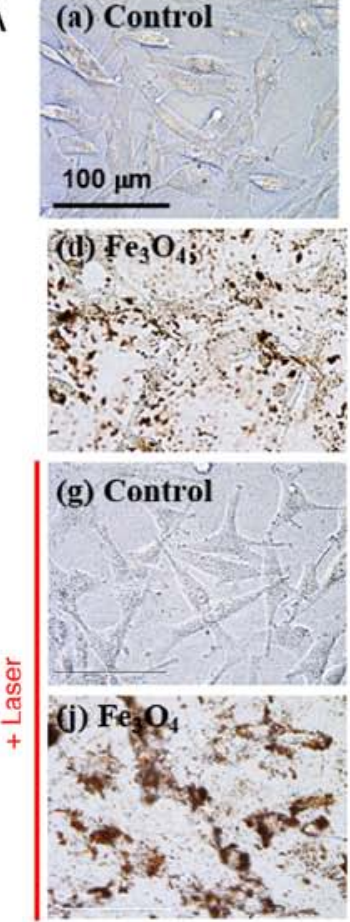

C
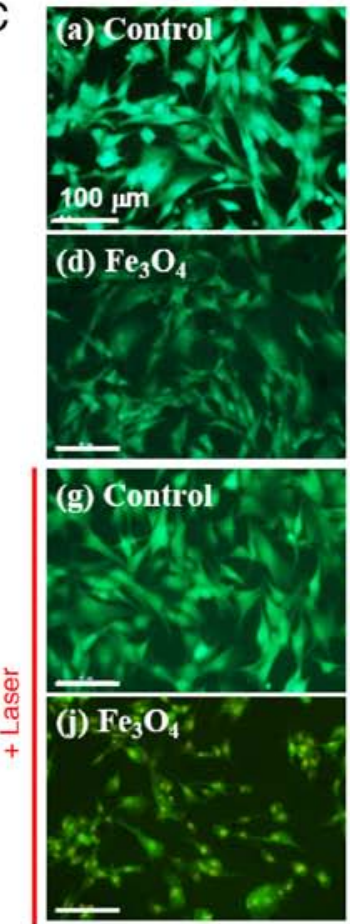
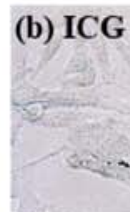

(e) $\mathrm{Fe}_{3} \mathrm{O}_{4} \mathrm{ICG}$

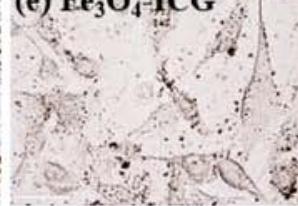

(h) ICG
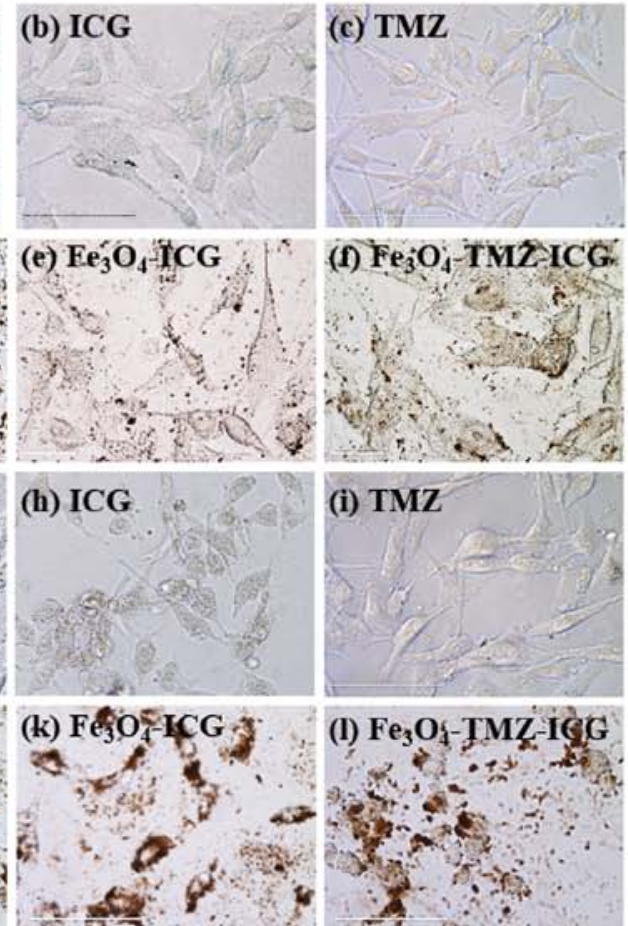

(i) TMZ
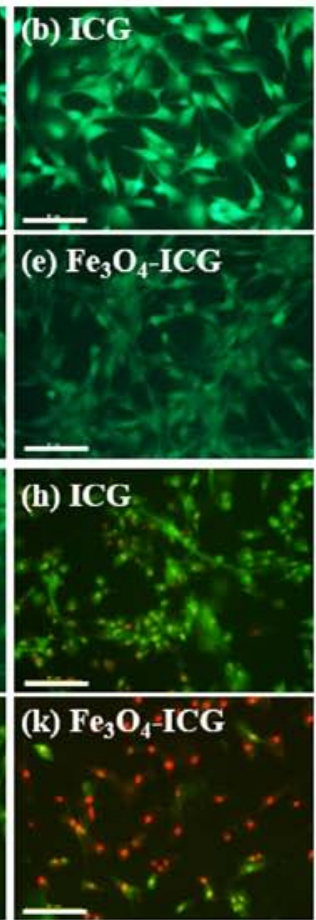
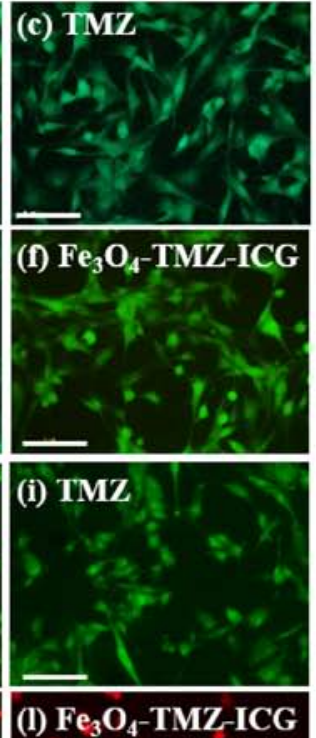
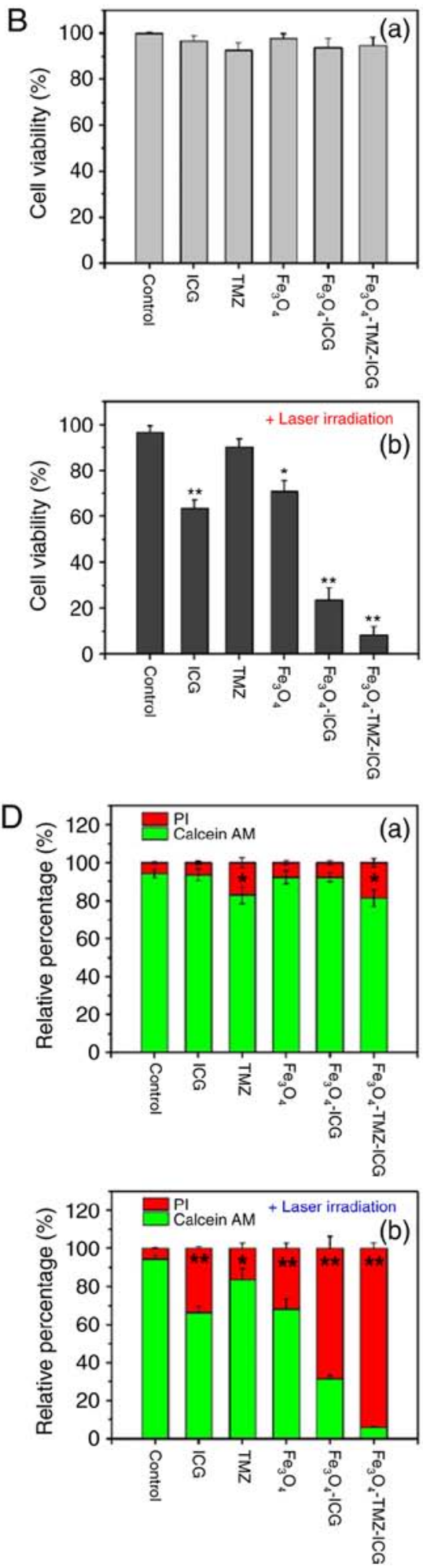

Figure 5. In vitro cytotoxicity and photothermal effect on U-87 MG cells. (A) In vitro morphological changes with various treatments by optical microscopy. (B) Relative cell viability by WST-1 assay with different samples (a) without or (b) with laser irradiation. (C) Fluorescence microscopy images of calcein AM/PI double stained U-87 MG cells with various treatments. (D) Quantitative analysis of live/dead cells calculated by ImageJ software (a) without or (b) with laser irradiation. U-87 MG cells were pre-treated with different samples: No sample (control), $3.1 \mu \mathrm{g} / \mathrm{ml}$ of ICG, $6.6 \mu \mathrm{g} / \mathrm{ml}$ of TMZ, and $125 \mu \mathrm{g}$ Fe/ml of $\mathrm{Fe}_{3} \mathrm{O}_{4}, \mathrm{Fe}_{3} \mathrm{O}_{4}$-ICG and $\mathrm{Fe}_{3} \mathrm{O}_{4}$-TMZ-ICG magnetic nanoparticles before NIR laser exposure. After $2 \mathrm{~h}$ incubation, the cells were treated with or without NIR laser irradiation for $5 \mathrm{~min}\left(1 \mathrm{~W} / \mathrm{cm}^{2}\right)$ followed by further incubation for $22 \mathrm{~h}$. All values were presented as the mean \pm standard deviation, $\mathrm{n}=3$; * $\mathrm{P}<0.05$ and ${ }^{* * *} \mathrm{P}<0.01$ vs. control. Scale bar, $100 \mu \mathrm{m}$. ICG, indocyanine green; NIR, near-infrared; TMZ, temozolomide.

group with NIR laser irradiation exhibited no marked changes in cell viability. There was no obvious change in temperature (data not shown). ICG and $\mathrm{Fe}_{3} \mathrm{O}_{4}$ MNPs with NIR laser irradiation revealed a total of 63.55 and $70.74 \%$ viable cells, respectively. The temperature increased up to 41.1 and $43.6^{\circ} \mathrm{C}$ for ICG and $\mathrm{Fe}_{3} \mathrm{O}_{4} \mathrm{MNPs}$, respectively (data not shown). The 
combination of ICG and $\mathrm{Fe}_{3} \mathrm{O}_{4}\left(\mathrm{Fe}_{3} \mathrm{O}_{4}\right.$-ICG) exhibited significantly decreased cell viability (21.37\%), leading to a notable temperature increase to $51.8^{\circ} \mathrm{C}$. Finally, the combination of ICG, TMZ and $\mathrm{Fe}_{3} \mathrm{O}_{4}\left(\mathrm{Fe}_{3} \mathrm{O}_{4}\right.$-TMZ-ICG) as a chemo-photothermal agent showed a significantly decreased cell viability of $9.32 \%$, leading to an obvious temperature increase to $51.2^{\circ} \mathrm{C}$.

According to these results, photothermal therapy by ICG, $\mathrm{Fe}_{3} \mathrm{O}_{4}$ and $\mathrm{Fe}_{3} \mathrm{O}_{4}$-ICG MNPs with 808-nm NIR laser irradiation induced marked morphological changes such as cell shrinkage, membrane integrity loss, and cytoplasmic condensation, evidencing the incidence of cell apoptosis (62). Moreover, $\mathrm{Fe}_{3} \mathrm{O}_{4}$-TMZ-ICG MNPs with 808-nm NIR laser irradiation induced severe cellular damage and showed significantly decreased in U-87 MG glioblastoma cell viability via the combination of chemo-photothermal therapy, resulting in subsequent irreversible cell death.

Live/dead cell assay. To further investigate the in vitro photothermal effect of combined chemo-photothermal therapy using TMZ- and ICG-loaded $\mathrm{Fe}_{3} \mathrm{O}_{4}$ MNPs, live cells detection after treatment with samples was carried out using calcein AM/PI double staining. As shown in Fig. 5C, the control U-87 MG cells with and without 808-nm NIR laser irradiation emitted green fluorescence as the calcein-AM reagent can penetrate the live cell membrane, indicating no apoptotic cells. Treatment with the ICG, $\mathrm{Fe}_{3} \mathrm{O}_{4}$, and $\mathrm{Fe}_{3} \mathrm{O}_{4}$-ICG MNPs without NIR laser irradiation showed green fluorescence, suggesting no cytotoxicity. In addition, treatment with TMZ and $\mathrm{Fe}_{3} \mathrm{O}_{4}$-TMZ-ICG MNPs showed slight morphological changes. However, treatment with $\mathrm{Fe}_{3} \mathrm{O}_{4}$ and ICG with NIR laser irradiation showed slight yellow-green calcein-AM nuclear staining with morphological damage, suggesting that there was the early cell apoptosis. Moreover, treatment with $\mathrm{Fe}_{3} \mathrm{O}_{4}$-TMZ-ICG MNPs with 808-nm NIR laser irradiation exhibited intense red fluorescence due to PI staining, suggesting that chemo-photothermal therapy using the $\mathrm{Fe}_{3} \mathrm{O}_{4}$-TMZ-ICG MNPs exhibited high cytotoxicity against U-87 MG cells.

To assess the live/dead cell ratio, calcein-AM and PI fluorescence intensities were quantified using ImageJ software (Fig. 5D). The cells treated with ICG, TMZ and/or $\mathrm{Fe}_{3} \mathrm{O}_{4}$ showed significantly increased cell death under NIR laser irradiation, as evidenced by fewer green spots and enhanced red spots in the images. These results demonstrated that chemo-photothermal therapy using $\mathrm{Fe}_{3} \mathrm{O}_{4}$-TMZ-ICG MNPs induced the synergetic effect for U-87 MG cancer cell killing capacity.

Nanoparticles intracellular uptake and cellular damage. To assess DNA damage-induced apoptosis by the synergistic combination of chemo-phototherapy, high-quality morphological images in single cells were observed via confocal microscopy. As shown in Fig. 6A-F, cells that unexposed to 808-nm NIR laser irradiation (i.e. no sample, $3.1 \mu \mathrm{g} / \mathrm{ml} \mathrm{ICG,}$ $6.6 \mu \mathrm{g} / \mathrm{ml} \mathrm{TMZ}$, and $125 \mathrm{mg} \mathrm{Fe} / \mathrm{ml} \mathrm{Fe}_{3} \mathrm{O}_{4}, \mathrm{Fe}_{3} \mathrm{O}_{4}$-ICG and $\mathrm{Fe}_{3} \mathrm{O}_{4}$-TMZ-ICG MNPs) showed no nuclear and cellular membrane damage. The cells treated with no sample (control) and TMZ with NIR laser irradiation also showed no notable nuclear and cellular membrane damage. On the contrary, the cells treated with ICG, $\mathrm{Fe}_{3} \mathrm{O}_{4}$, and ICG-conjugated $\mathrm{Fe}_{3} \mathrm{O}_{4}$ as photothermal agents under NIR laser irradiation exhibited considerable nuclear damage and the loss of cellular membrane integrity (Fig. 6G-L). In particular, as shown Fig. 6J-L, $\mathrm{Fe}_{3} \mathrm{O}_{4}$ nanoparticles exhibited enhanced intracellular nanoparticle uptake by $808-\mathrm{nm}$ NIR laser stimulation, thereby leading to nucleus damage. These results suggest that $\mathrm{Fe}_{3} \mathrm{O}_{4}$-TMZ-ICG MNPs as a TMZ drug carrier were more highly internalized into the nucleus of cancer cells by NIR laser stimuli; TMZ from the surface of $\mathrm{Fe}_{3} \mathrm{O}_{4}$ MNPs may bind DNA contributing to efficient targeted drug delivery.

Determination of cell apoptosis. To investigate the synergistic anticancer effect of the combination of chemo-phototherapy compared to chemotherapy and phototherapy alone, flow cytometry analysis was conducted after treatment with samples (i.e., no sample, $3.1 \mu \mathrm{g} / \mathrm{ml}$ of ICG, $6.6 \mu \mathrm{g} / \mathrm{ml}$ of TMZ, and $125 \mu \mathrm{g} \mathrm{Fe} / \mathrm{ml}$ of $\mathrm{Fe}_{3} \mathrm{O}_{4}, \mathrm{Fe}_{3} \mathrm{O}_{4}$-ICG and $\mathrm{Fe}_{3} \mathrm{O}_{4}$-TMZ-ICG MNPs) using Annexin V-FITC/PI double staining (Fig. 7). For the control with or without 808-nm NIR laser treatment, there was no cytotoxicity, indicating the control group was not affected by NIR laser irradiation. For the cells after treatment with samples without 808-nm NIR laser, there were no significant cytotoxicity compared with the control. In contrast, the cells after treatment of samples with 808-nm NIR laser exhibited significantly higher cytotoxicity with an increase in the proportion of cell apoptosis, except for TMZ treatment. This suggested that the decrease in cell viability may be due to apoptosis by phototherapy and/or chemo-phototherapy. Here, the observed percentages of apoptotic cells (early and late apoptotic cells) after 808-nm NIR laser treatment were $2.06 \%$ in control, $35.3 \%$ in ICG-treated $(3.1 \mu \mathrm{g} / \mathrm{ml}), 6.23 \%$ in TMZ-treated $(6.6 \mu \mathrm{g} / \mathrm{ml}), 30.27 \%$ in $\mathrm{Fe}_{3} \mathrm{O}_{4}$-treated $(125 \mu \mathrm{g}$ $\mathrm{Fe} / \mathrm{ml}), 71.40 \%$ in $\mathrm{Fe}_{3} \mathrm{O}_{4}$-ICG-treated $(125 \mu \mathrm{g} \mathrm{Fe} / \mathrm{ml})$, and $85.58 \%$ in $\mathrm{Fe}_{3} \mathrm{O}_{4}$-TMZ-ICG-treated $(125 \mu \mathrm{g} \mathrm{Fe} / \mathrm{ml})$ cells, respectively. Specifically, the $\mathrm{Fe}_{3} \mathrm{O}_{4}$-TMZ-ICG MNPs without 808-nm NIR laser irradiation showed a cytotoxicity of $6.7 \%$ against U-87 MG cells; however, U-87 MG cells treated with the $\mathrm{Fe}_{3} \mathrm{O}_{4}$-TMZ-ICG MNPs under 808-nm NIR laser irradiation showed significantly increased cell cytotoxicity of $96.68 \%$ after $12 \mathrm{~h}$ treatment. In addition, treatment with $\mathrm{Fe}_{3} \mathrm{O}_{4}$-TMZ-ICG and 808-nm NIR laser irradiation at $1 \mathrm{~W} / \mathrm{cm}^{2}$ for $5 \mathrm{~min}$ led to a total of $\sim 80 \%$ apoptotic cells. Therefore, the $\mathrm{Fe}_{3} \mathrm{O}_{4}$-TMZ-ICG MNPs with 808-nm NIR laser irradiation at $1 \mathrm{~W} / \mathrm{cm}^{2}$ may be effectively utilized as a photothermal-induced anticancer therapeutic agent in synergistic cancer therapy.

Promotion of intrinsic and extrinsic apoptotic pathway. Apoptosis known as programmed cell death is regulated by specific cellular signaling pathways which maintain the balance between cell proliferation and cell death (49). Cancer can occur when the balance of cell division and cell death is disturbed, and defects in apoptosis can cause tumor pathogenesis (63). Thus, a key goal of cancer therapy is to promote the apoptosis of cancer cells without damage to normal cells (64). It has been reported that nanoparticle-mediated photothermal therapy induces apoptosis $(65,66)$. Apoptosis is characterized by two main intrinsic and extrinsic apoptotic pathways (67). Upon exposure to external and internal stress stimuli, p53, a nuclear transcription factor, promotes apoptotic function by 

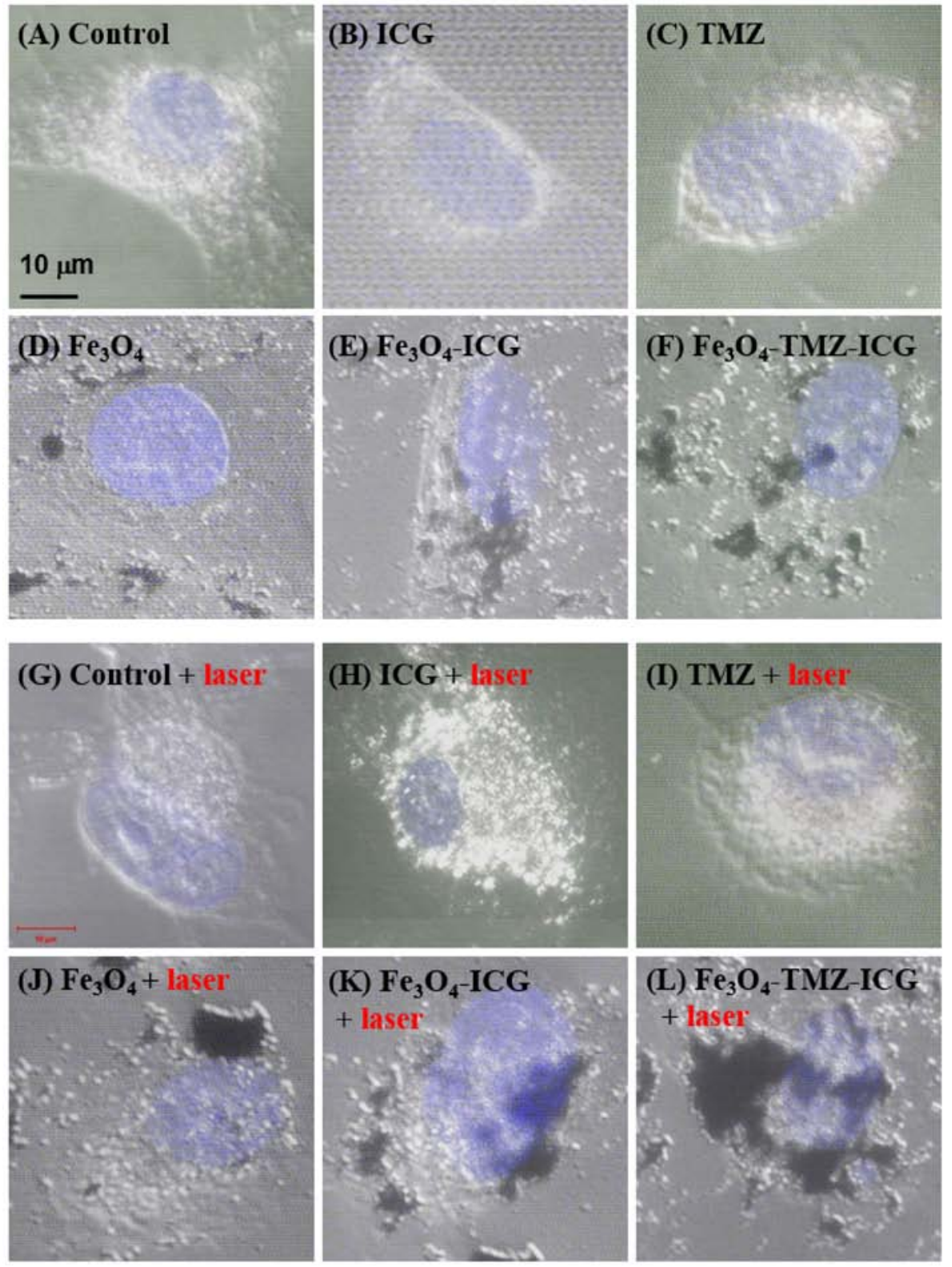

Figure 6. Confocal laser scanning microscopy images of photothermal effect on U-87 MG cells. The cells were pre-treated with different samples (i.e., no sample, $3.1 \mu \mathrm{g} / \mathrm{ml}$ of ICG, $6.6 \mu \mathrm{g} / \mathrm{ml}$ of TMZ, and $125 \mu \mathrm{g} \mathrm{Fe} / \mathrm{ml}$ of $\mathrm{Fe}_{3} \mathrm{O}_{4}, \mathrm{Fe}_{3} \mathrm{O}_{4}-\mathrm{ICG}$ and $\mathrm{Fe}_{3} \mathrm{O}_{4}$-TMZ-ICG magnetic nanoparticles) before NIR laser exposure. After $2 \mathrm{~h}$ incubation, the cells were treated with or without NIR laser irradiation for $5 \mathrm{~min}\left(1 \mathrm{~W} / \mathrm{cm}^{2}\right)$ followed by further incubation for $22 \mathrm{~h}$. Scale bar, $10 \mu \mathrm{m}$. ICG, indocyanine green; NIR, near-infrared; TMZ, temozolomide.

the regulation of apoptotic protein expression of both extrinsic and intrinsic pathways (68). In the intrinsic pathway, p53 modulates the Bcl-2 family of proteins, including pro-apoptotic Bax and anti-apoptotic Bcl-2. The Bcl-2 protein family comprise central regulators of the intrinsic apoptotic pathway, which control cytochrome $c$ release from the mitochondria to the cytosol and induce the activation of caspase-3 (69).

In the present study, ICG, $\mathrm{Fe}_{3} \mathrm{O}_{4}$, and ICG-conjugated $\mathrm{Fe}_{3} \mathrm{O}_{4}$ MNPs with NIR laser stimuli was determined to induce apoptotic cell death through ROS generation and photothermal effects. Intrinsic apoptotic pathways can be initiated by elevated intracellular ROS generation (70). Thus, we first evaluated ROS-mediated intrinsic apoptotic protein including Bax, Bcl-2, cytochrome $c$, and caspase- 3 by western blotting. As depicted in Fig. 8A and B, ICG, $\mathrm{Fe}_{3} \mathrm{O}_{4}$, and ICG-conjugated $\mathrm{Fe}_{3} \mathrm{O}_{4}$ MNPs with NIR laser irradiation significantly upregulated pro-apoptotic Bax, but downregulated anti-apoptotic $\mathrm{Bcl}-2$ protein expression compared with the control. Next, we confirmed that cytochrome $c$ accumulation in the cytosolic extract was significantly increased by chemo-photothermal therapy using ICG, $\mathrm{Fe}_{3} \mathrm{O}_{4}$, and their conjugates, compared with the control. In addition, western blot analysis showed upregulation of caspase-3 activation by chemo-photothermal therapy using ICG, TMZ, $\mathrm{Fe}_{3} \mathrm{O}_{4}$, and their conjugates, as evidenced by increased caspase- 3 cleavage fragments. Our data demonstrated that the combination of chemo-photothermal therapy using $\mathrm{Fe}_{3} \mathrm{O}_{4}$-TMZ-ICG MNPs notably promoted the intrinsic apoptosis-related pathway compared with ICG, TMZ, and $\mathrm{Fe}_{3} \mathrm{O}_{4}$ alone. The fold increase in Bax, cytochrome $c$ release into the cytosol, and caspase- 3 activation, and the fold decrease in $\mathrm{Bcl}-2$ expression due to $\mathrm{Fe}_{3} \mathrm{O}_{4}$-TMZ-ICG MNPs was 5.79, $3.91,4.92$ and 0.16 compared with the control, respectively. 


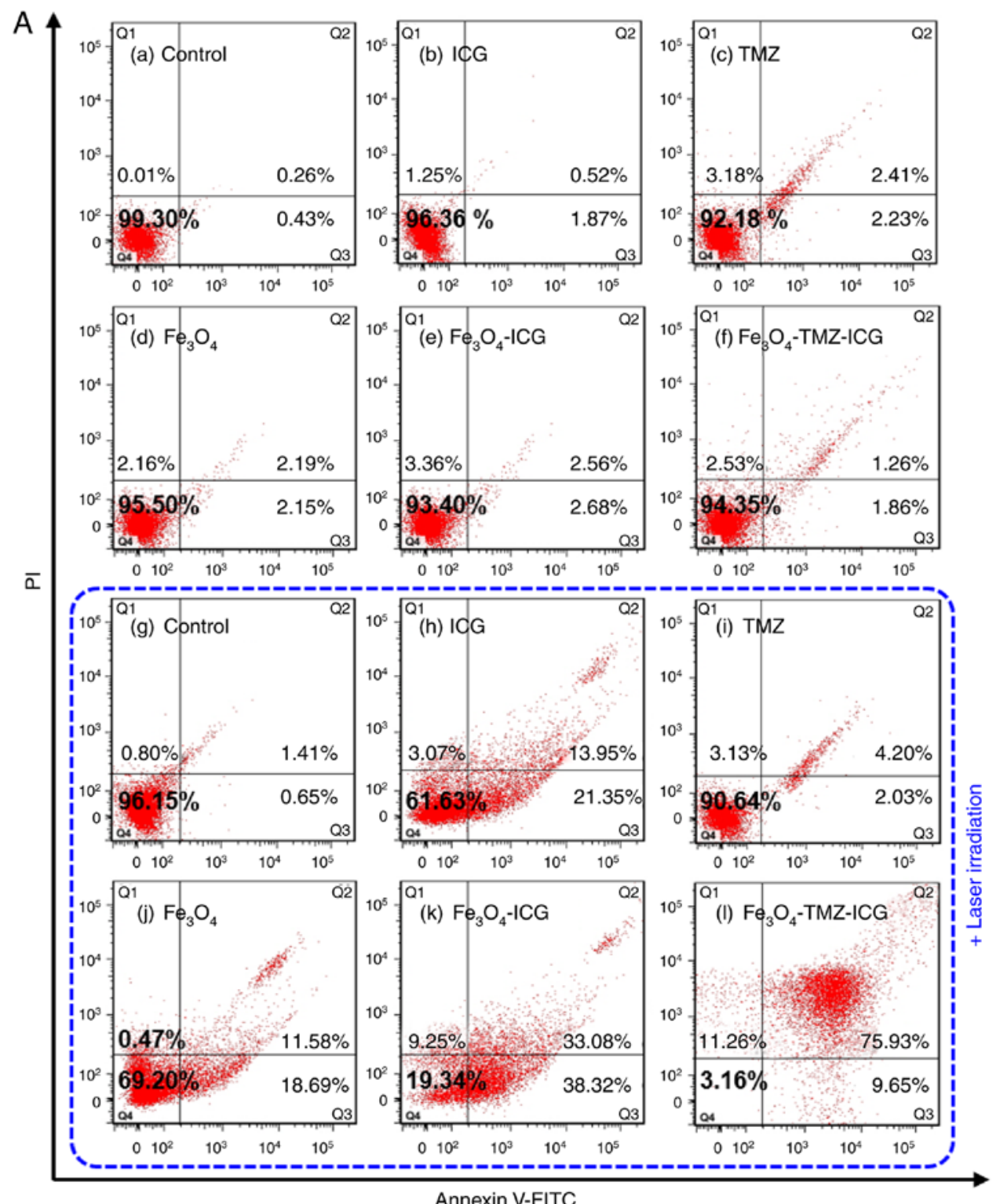

Annexin V-FITC

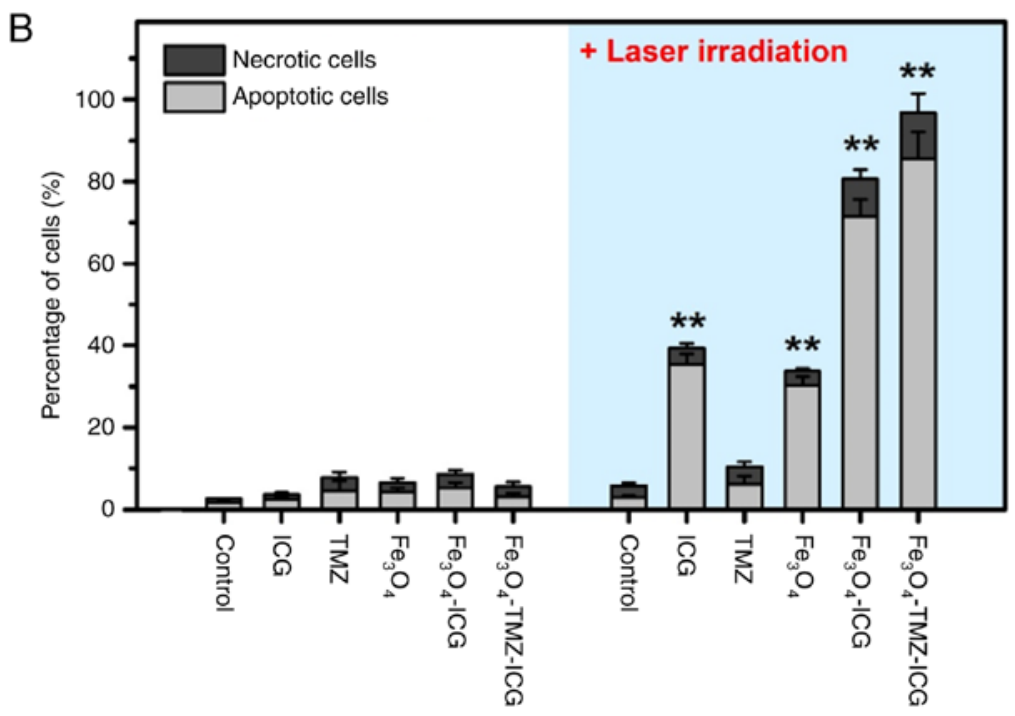

Figure 7. Photothermally-induced apoptosis analysis by flow cytometry in U-87 MG cells. (A) Representative of dot plots and (B) quantification of the apoptotic and necrotic cells in U-87 MG cells stained with Annexin V-FITC/PI double staining kit. The cells were pre-treated with different samples: No sample (control), $3.1 \mu \mathrm{g} / \mathrm{ml}$ of ICG, $6.6 \mu \mathrm{g} / \mathrm{ml}$ of TMZ, and $125 \mu \mathrm{g} \mathrm{Fe} / \mathrm{ml}$ of $\mathrm{Fe}_{3} \mathrm{O}_{4}, \mathrm{Fe}_{3} \mathrm{O}_{4}$-ICG and $\mathrm{Fe}_{3} \mathrm{O}_{4}$-TMZ-ICG magnetic nanoparticles, before near-infrared laser exposure. After $2 \mathrm{~h}$ incubation, the cells were treated with or without NIR laser irradiation for $5 \mathrm{~min}\left(1 \mathrm{~W} / \mathrm{cm}^{2}\right)$ followed by further incubation for $22 \mathrm{~h}$. All values were presented as the mean \pm standard deviation, $\mathrm{n}=3 ;{ }^{* *} \mathrm{P}<0.01$ vs. control. FITC, fluorescein isothiocyanate; ICG, indocyanine green; NIR, near-infrared; PI, propidium iodide; TMZ, temozolomide. 
A
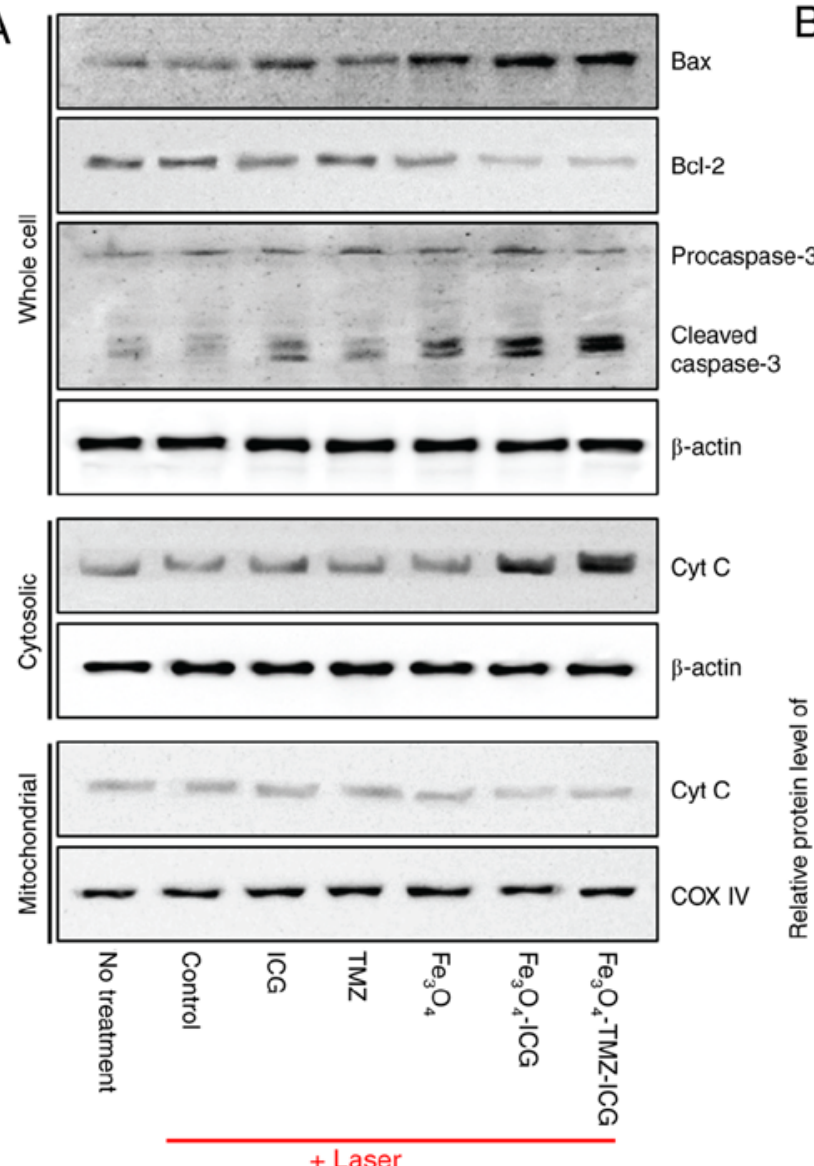

B
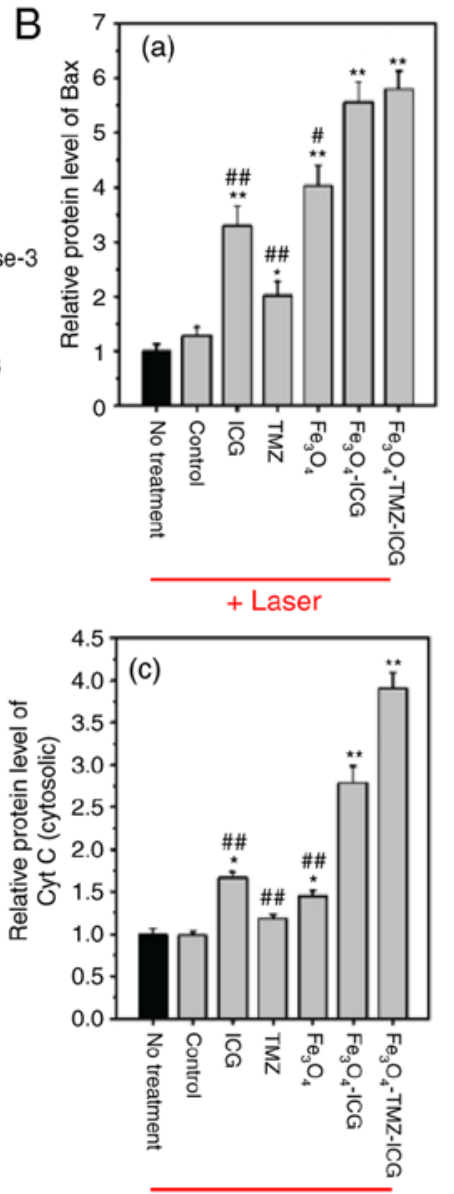

+ Laser
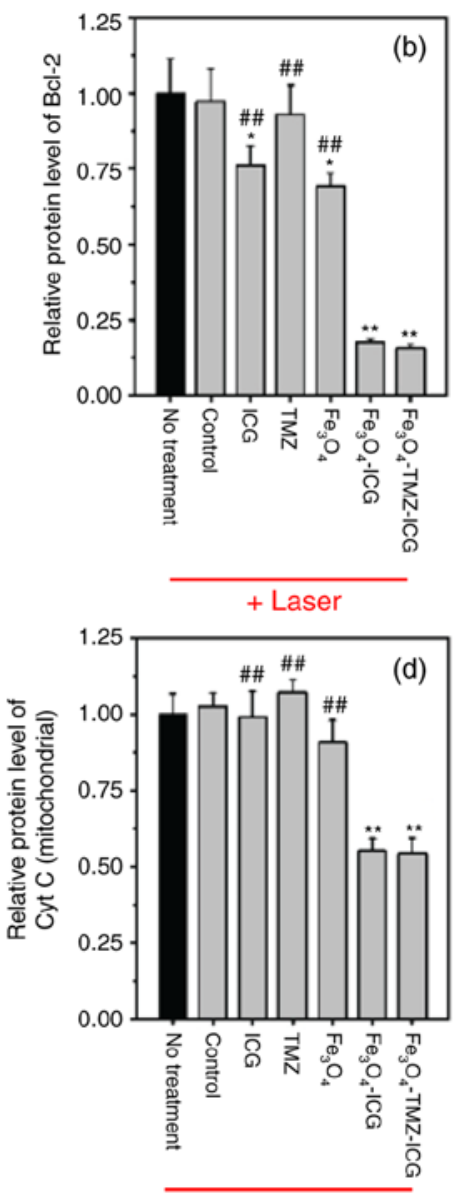

+ Laser

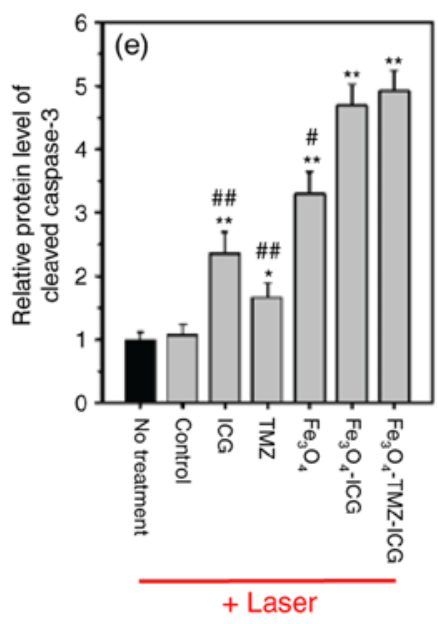

Figure 8. Western blotting analysis of apoptosis-related proteins regulated by photothermal therapy in U-87 MG cells. (A) Representative western of Bax, Bcl-2, procaspase-3, cleaved caspase-3, cytosolic cytochrome $c$, and mitochondrial cyt c. $\beta$-actin and COX IV were used as loading controls. (B) Quantitative analysis of relative protein expression of Bax, Bcl-2, cleaved caspase-3, cytosolic cyt c, and mitochondrial cyt c using ImageJ software. Quantification of protein expressions of Bax, Bcl-2, and cleaved caspase-3 were normalized to $\beta$-actin; that of cytosolic cyt $\mathrm{c}$, and mitochondrial cyt $\mathrm{c}$ were normalized to $\beta$-actin and COX IV, respectively. All values were presented as the mean \pm standard deviation, $\mathrm{n}=3$; ${ }^{*} \mathrm{P}<0.05$ and ${ }^{* * *} \mathrm{P}<0.01$ vs. untreated control (no treatment); ${ }^{\#} \mathrm{P}<0.05$ and ${ }^{\# \#} \mathrm{P}<0.01$ vs. $\mathrm{Fe}_{3} \mathrm{O}_{4}$-TMZ-ICG with NIR laser irradiation; Bax, Bcl-2-associated X protein; cyt c, cytochrome $c$; COX IV, cytochrome $c$ oxidase; ICG, indocyanine green; NIR, near-infrared; TMZ, temozolomide.

These results suggest that chemo-photothermal therapy exhibited notable anti-cancer effects against U-87 MG cells through stimulation of intrinsic apoptosis-related pathway.

The extrinsic pathway is initiated by the binding of an extracellular death ligand to its cell surface death receptors, and influences the activation of the death receptor FADD-caspase- 8 pathway, which can directly activate caspase-3 (71). To investigate the molecular mechanism of extrinsic apoptosis in chemo-photothermal therapy using ICG, $\mathrm{Fe}_{3} \mathrm{O}_{4}$, and ICG-conjugated $\mathrm{Fe}_{3} \mathrm{O}_{4}$ MNPs, the mRNA expression of FADD and caspase- 8 genes were analyzed by RT-qPCR. As shown in Fig. 9, ICG, $\mathrm{Fe}_{3} \mathrm{O}_{4}$, and ICG-conjugated $\mathrm{Fe}_{3} \mathrm{O}_{4}$ MNPs with NIR laser irradiation significantly upregulated the mRNA expression of FADD and caspase- 8 compared 

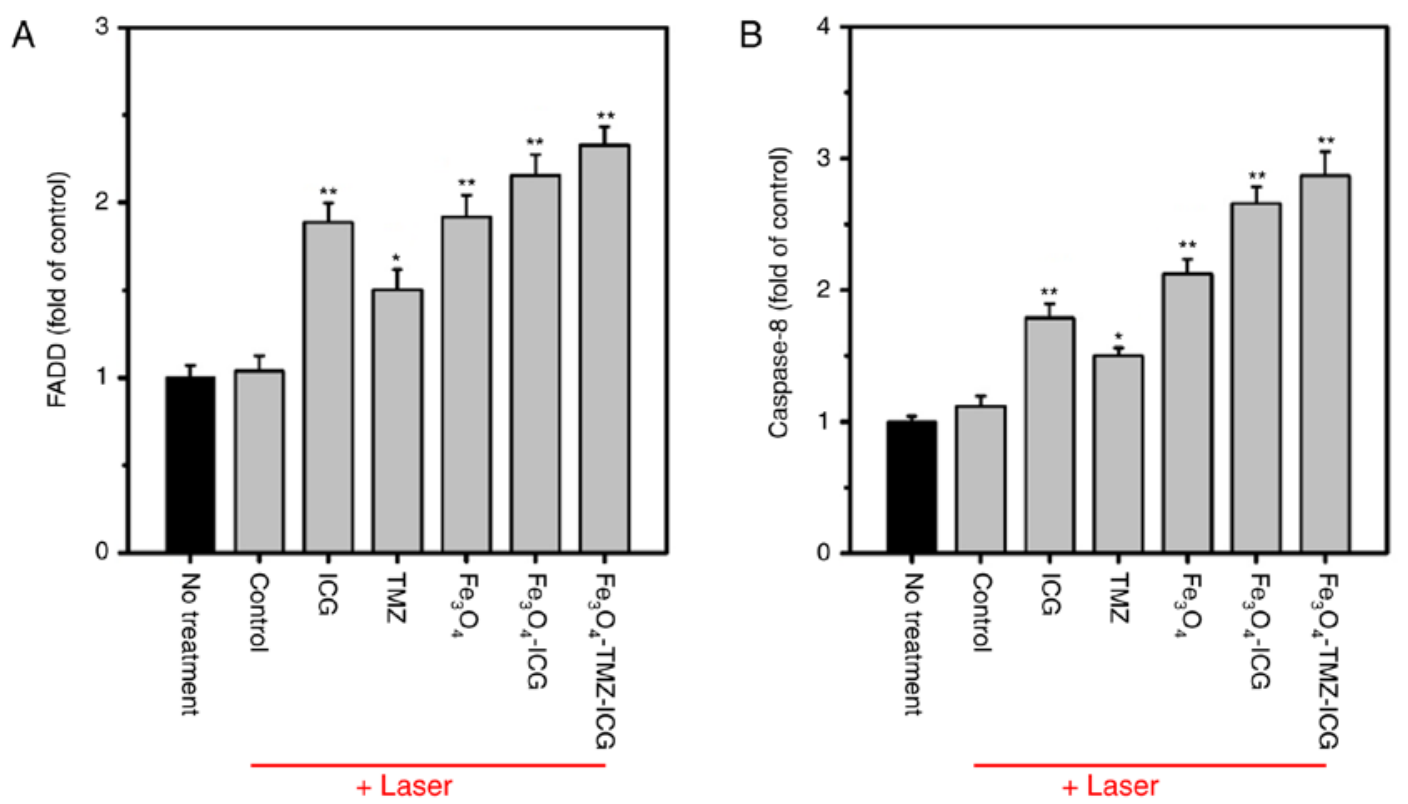

Figure 9. Reverse transcription-quantitative polymerase chain reaction analysis of mRNA expression profile of genes associated with the extrinsic apoptotic signalling pathway. Expression of (A) FADD and (B) caspase-8 following photothermal therapy in U-87 MG cells pre-treated with different samples (no sample, $3.1 \mu \mathrm{g} / \mathrm{ml}$ of ICG, $6.6 \mu \mathrm{g} / \mathrm{ml}$ of TMZ, and $125 \mu \mathrm{g} \mathrm{Fe} / \mathrm{ml}$ of $\mathrm{Fe}_{3} \mathrm{O}_{4}, \mathrm{Fe}_{3} \mathrm{O}_{4}-\mathrm{ICG}$ and $\mathrm{Fe}_{3} \mathrm{O}_{4}$-TMZ-ICG magnetic nanoparticles) for $2 \mathrm{~h}$ followed by near-infrared laser irradiation for $5 \mathrm{~min}\left(1 \mathrm{~W} / \mathrm{cm}^{2}\right)$ and subsequent incubation for $22 \mathrm{~h}$. Untreated cells with no sample served as the control. All values were presented as mean \pm standard deviation, $\mathrm{n}=3 ;{ }^{*} \mathrm{P}<0.05$ and ${ }^{* *} \mathrm{P}<0.01$ vs. untreated control. FADD, Fas associated via death domain; ICG, indocyanine green; TMZ, temozolomide.

with the control. The combination of chemo-photothermal therapy using $\mathrm{Fe}_{3} \mathrm{O}_{4}$-TMZ-ICG MNPs resulted in markedly higher mRNA expression of FADD and caspase-8 (2.33 and 2.87-fold, respectively) compared with ICG, TMZ, and $\mathrm{Fe}_{3} \mathrm{O}_{4}$ alone. These results support the chemo-photothermal effects of $\mathrm{Fe}_{3} \mathrm{O}_{4}$-TMZ-ICG MNPs in promoting the apoptotic of U-87 MG cells via upregulation of extrinsic apoptosis-related genes. Taken together, chemo-photothermal therapy using $\mathrm{Fe}_{3} \mathrm{O}_{4}$-TMZ-ICG MNPs exhibited the most notable anti-cancer effect by inducing apoptosis through activation of the intrinsic and extrinsic pathways.

In this study, we prepared ICG- and TMZ-loaded $\mathrm{Fe}_{3} \mathrm{O}_{4}$ MNPs, and demonstrated their chemo-phototherapeutic synergistic effect against U-87 MG glioblastoma cells. The ICG-embedded $\mathrm{Fe}_{3} \mathrm{O}_{4}$ MNPs exhibited excellent photothermal effect and photostability under NIR laser irradiation. Further, TMZ- and ICG-loaded $\mathrm{Fe}_{3} \mathrm{O}_{4}$ MNPs exhibited synergistic cell cytotoxicity when applied via chemo-phototherapy. The experimental results showed that the combination of chemo-phototherapy using the $\mathrm{Fe}_{3} \mathrm{O}_{4}$-TMZ-ICG MNPs induced effective cancer cell death mediated by enhanced ROS generation, and modulated both the intrinsic and extrinsic apoptotic pathways. Therefore, our results demonstrated that the synthesized NIR-light-responsive $\mathrm{Fe}_{3} \mathrm{O}_{4}$-TMZ-ICG MNPs could be promising phototherapeutic agents for the treatment of glioblastoma.

\section{Acknowledgements}

Not applicable.

\section{Funding}

No funding was received.

\section{Availability of data and materials}

All data used and analyzed during the current study are available from the corresponding author on reasonable request.

\section{Authors' contributions}

YMK prepared the nanoparticles and drafted the manuscript. JYJ contributed to the design of nanoparticles and performed the cell experiments. SHC characterized the nanoparticles and interpreted the data. YO performed the in vitro experiments and contributed to the final version of the manuscript. WHC made substantial contributions to the design of the present study and supervised the experiments. All authors discussed the results and approved the final manuscript.

\section{Ethics approval and consent to participate}

Not applicable.

\section{Patient consent for publication}

Not applicable.

\section{Competing interests}

The authors declare that they have no competing interests.

\section{References}

1. Stupp R, Taillibert S, Kanner A, Read W, Steinberg D, Lhermitte B, Toms S, Idbaih A, Ahluwalia MS, Fink K, Di Meco F, et al: Effect of tumor-treating fields plus maintenance temozolomide vs maintenance temozolomide alone on survival in patients with glioblastoma: A randomized clinical trial. JAMA 318: 2306-2316, 2017. 
2. Ladomersky E, Scholtens DM, Kocherginsky M, Hibler EA, Bartom ET, Otto-Meyer S, Zhai L, Lauing KL, Choi J, Sosman JA, et al: The coincidence between increasing age, immunosuppression, and the incidence of patients with glioblastoma. Front Pharmacol 10: 200, 2019.

3. Ostrom QT, Gittleman H, Truitt G, Boscia A, Kruchko C and Barnholtz-Sloan JS: CBTRUS statistical report: Primary brain and other central nervous system tumors diagnosed in the United States in 2011-2015. Neuro Oncol 20 (Suppl 4): iv1-iv86, 2018.

4. Harder BG, Blomquist MR, Wang J, Kim AJ, Woodworth GF, Winkles JA, Loftus JC and Tran NL: Developments in blood-brain barrier penetrance and drug repurposing for improved treatment of glioblastoma. Front Oncol 8: 462, 2018.

5. Shergalis A, Bankhead A III, Luesakul U, Muangsin N and Neamati N: Current challenges and opportunities in treating glioblastoma. Pharmacol Rev 70: 412-445, 2018

6. Van Tellingen O, Yetkin-Arik B, De Gooijer MC, Wesseling P, Wurdinger $\mathrm{T}$ and de Vries HE: Overcoming the blood-brain tumor barrier for effective glioblastoma treatment. Drug Resist Updat 19: 1-12, 2015.

7. Minniti G, Muni R, Lanzetta G, Marchetti P and Enrici RM: Chemotherapy for glioblastoma: Current treatment and future perspectives for cytotoxic and targeted agents. Anticancer Res 29: 5171-5184, 2009.

8. Friedman HS, Kerby $\mathrm{T}$ and Calvert H: Temozolomide and treatment of malignant glioma. Clin Cancer Res 6: 2585-2597, 2000.

9. Agarwala SS and Kirkwood JM: Temozolomide, a novel alkylating agent with activity in the central nervous system, may improve the treatment of advanced metastatic melanoma. Oncologist 5: 144-151, 2000.

10. O'Neal DP, Hirsch LR, Halas NJ, Payne JD and West JL: Photo-thermal tumor ablation in mice using near infrared-absorbing nanoparticles. Cancer Lett 209: 171-176, 2004

11. Fang J and Chen YC: Nanomaterials for photohyperthermia: A review. Curr Pharm Des 19: 6622-6634, 2013.

12. Zhang W, Guo Z, Huang D, Liu Z, Guo X and Zhong H: Synergistic effect of chemo-photothermal therapy using PEGylated graphene oxide. Biomaterials 32: 8555-8561, 2011.

13. Zhang H, Sun Y, Huang R, Cang H, Cai Z and Sun B: pH-sensitive prodrug conjugated polydopamine for NIR-triggered synergistic chemo-photothermal therapy. Eur J Pharm Biopharm 128 : 260-271, 2018

14. Chen R, Zheng X, Qian H, Wang X, Wang J and Jiang X: Combined near-IR photothermal therapy and chemotherapy using gold-nanorod/chitosan hybrid nanospheres to enhance the antitumor effect. Biomater Sci 1: 285-293, 2013

15. El-Sayed IH, Huang X and El-Sayed MA: Selective laser photo-thermal therapy of epithelial carcinoma using anti-EGFR antibody conjugated gold nanoparticles. Cancer Lett 239: $129-135,2006$

16. Huang X, Jain PK, El-Sayed IH and El-Sayed MA: Plasmonic photothermal therapy (PPTT) using gold nanoparticles. Lasers Med Sci 23: 217-228, 2008

17. Wiley BJ, Chen Y, McLellan JM, Xiong Y, Li ZY, Ginger D and Xia Y: Synthesis and optical properties of silver nanobars and nanorice. Nano Lett 7: 1032-1036, 2007.

18. Hirsch LR, Gobin AM, Lowery AR, Tam F, Drezek RA, Halas NJ and West JL: Metal nanoshells. Ann Biomed Eng 34 15-22, 2006.

19. Conde J, Doria G and Baptista P: Noble metal nanoparticles applications in cancer. J Drug Deliv 2012: 751075, 2012.

20. Li Y, Lu W, Huang Q, Li C and Chen W: Copper sulfide nanoparticles for photothermal ablation of tumor cells. Nanomedicine (Lond) 5: 1161-1171, 2010.

21. Robinson JT, Tabakman SM, Liang Y, Wang H, Casalongue HS, Vinh D and Dai H: Ultrasmall reduced graphene oxide with high near-infrared absorbance for photothermal therapyJ Am Chem Soc 133: 6825-6831, 2011.

22. Gao J, Gu H and Xu B: Multifunctional magnetic nanoparticles: Design, synthesis, and biomedical applications. Acc Chem Res 42: 1097-1107, 2009.

23. Lee S, George Thomas R, Ju Moon M, Ju Park H, Park IK, Lee BI and Yeon Jeong Y: Near-infrared heptamethine cyanine based iron oxide nanoparticles for tumor targeted multimodal imaging and photothermal therapy. Sci Rep 7: 2108, 2017.

24. Shen S, Kong F, Guo X, Wu L, Shen H, Xie M, Wang X, Jin Y and $\mathrm{Ge}$ Y: CMCTS stabilized Fe3O4 particles with extremely low toxicity as highly efficient near-infrared photothermal agents for in vivo tumor ablation. Nanoscale 5: 8056-8066, 2013.
25. Sadat M, Kaveh Baghbador M, Dunn AW, Wagner HP, Ewing CR, Zhang J, Xu H,Pauletti GM, MastDB and Shi D: Photoluminescence and photothermal effect of $\mathrm{Fe}_{3} \mathrm{O}_{4}$ nanoparticles for medical imaging and therapy. Appl Phys Lett 105: 091903, 2014

26. Chen H, Burnett J, Zhang F, Zhang J, Paholak H and Sun D Highly crystallized iron oxide nanoparticles as effective and biodegradable mediators for photothermal cancer therapy. J Mater Chem B 2: 757-765, 2014.

27. Yuan G, Yuan Y, Xu K and Luo Q: Biocompatible PEGylated $\mathrm{Fe}_{3} \mathrm{O}_{4}$ nanoparticles as photothermal agents for near-infrared light modulated cancer therapy. Int J Mol Med Sci 15: 18776-18788, 2014.

28. Zhang Y: Photothermal effect of PS coated Fe3O4 nanoparticles via near-infrared laser and effect of mimic body tissue depth on hyperthermic ablation of MDA-MB-231. Univ Cincinnati, 2015.

29. Baronzio G, Parmar G, Ballerini M, Szasz A, Baronzio M and Cassutti V: A brief overview of hyperthermia in cancer treatment. J Integr Oncol 3: 115, 2014.

30. Fernandes C, Suares D and Yergeri MC: Tumor microenvironment targeted nanotherapy. Front Pharmacol 9: 1230, 2018.

31. Siemann DW: The unique characteristics of tumor vasculature and preclinical evidence for its selective disruption by tumor-vascular disrupting agents. Cancer Treat Rev 37: 63-74, 2011.

32. Ahmed K and Zaidi SF: Treating cancer with heat: Hyperthermia as promising strategy to enhance apoptosis. J Pak Med Assoc 63: 504-508, 2013

33. Melamed JR, Edelstein RS and Day ES: Elucidating the fundamental mechanisms of cell death triggered by photothermal therapy. ACS Nano 9: 6-11, 2015.

34. May JP and Li SD: Hyperthermia-induced drug targeting. Expert Opin Drug Deliv 10: 511-527, 2013.

35. Song C, Park H, Lee C and Griffin R: Implications of increased tumor blood flow and oxygenation caused by mild temperature hyperthermia in tumor treatment. Int J Hyperthermia 21: 761-767, 2005.

36. Bao Z, Liu X, Liu Y, Liu $\mathrm{H}$ and Zhao K: Near-infrared light-responsive inorganic nanomaterials for photothermal therapy. Asian J Pharm Sci 11: 349-364, 2016.

37. Zheng X, Zhou F, Wu B, Chen WR and Xing D: Enhanced tumor treatment using biofunctional indocyanine green-containing nanostructure by intratumoral or intravenous injection. Mol Pharm 9: 514-522, 2012

38. Xie J, Peng S, Brower N, Pourmand N, Wang SX and Sun S: One-pot synthesis of monodisperse iron oxide nanoparticles for potential biomedical applications. Pure Appl Chem 78: 1003-1014, 2006.

39. Jiang L, Zhou X, Wei G, Lu X, Wei W and Qiu J: Preparation and characterization of poly(glycidyl methacrylate)-grafted magnetic nanoparticles: Effects of the precursor concentration on polyol synthesis of $\mathrm{Fe}_{3} \mathrm{O}_{4}$ and [PMDETA]0/[CuBr2]0 ratios on SI-AGET ATRP. Appl Surf Sci 357: 1619-1624, 2015.

40. Feng G, Jiang L, Wen P, Cui Y, Li H and Hu D: A new ion-exchange adsorbent with paramagnetic properties for the separation of genomic DNA. Analyst 136: 4822-4829, 2011.

41. Li H, Shan Y, Qiao L, Dou A, Shi X and Xu G: Facile synthesis of boronate-decorated polyethyleneimine-grafted hybrid magnetic nanoparticles for the highly selective enrichment of modified nucleosides and ribosylated metabolites. Anal Chem 85: 11585-11592, 2013.

42. Bertucci A, Prasetyanto EA, Septiadi D, Manicardi A Brognara E, Gambari R, Corradini R and De Cola L: Combined delivery of temozolomide and anti-miR221 PNA using mesoporous silica nanoparticles induces apoptosis in resistant glioma cells. Small 11: 5687-5695, 2015.

43. Razak AA, Masthanamma S, Omshanthi B, Suresh V and Obulamma P: Development and validation of UV method of temozolomide in bulk and capsule formulation. Int J Pharm Sci Res 4: 1419, 2013.

44. Ma Y, Tong S, Bao G, Gao C and Dai Z: Indocyanine green loaded SPIO nanoparticles with phospholipid-PEG coating for dual-modal imaging and photothermal therapy. Biomaterials 34 : 7706-7714, 2013 .

45. Kim JH, Ramasamy T, Tran TH, Choi JY, Cho HJ, Yong CS and Kim JO: Polyelectrolyte complex micelles by self-assembly of polypeptide-based triblock copolymer for doxorubicin delivery. Asian J Pharm Sci 9: 191-198, 2014.

46. Allen M, Bjerke M, Edlund H, Nelander S and Westermark B Origin of the U87MG glioma cell line: Good news and bad news. Sci Transl Med 8: 354re3, 2016.

47. Niu $\mathrm{C}, \mathrm{Xu} \mathrm{Y}$, An S, Zhang M, Hu Y, Wang L and Peng Q: Near-infrared induced phase-shifted ICG/ $/ \mathrm{Fe}_{3} \mathrm{O}_{4}$ loaded PLGA nanoparticles for photothermal tumor ablation. Sci Rep 7: 5490 , 2017. 
48. Eruslanov E and Kusmartsev S: Identification of ROS using oxidized DCFDA and flow-cytometry. In: Advanced protocols in oxidative stress II Springer, pp57-72, 2010.

49. Elmore S: Apoptosis: A review of programmed cell death. Toxicol Pathol 35: 495-516, 2007.

50. Sanfilippo S, Canis M, Ouchchane L, Botchorishvili R, Artonne C, Janny L and Brugnon F: Viability assessment of fresh and frozen/thawed isolated human follicles: Reliability of two methods (Trypan blue and Calcein AM/ethidium homodimer-1). J Assist Reprod Genet 28: 1151-1156, 2011.

51. Zhou S, Cui Z and Urban J: Dead cell counts during serum cultivation are underestimated by the fluorescent live/dead assay. Biotechnol J 6: 513-518, 2011.

52. Tawakoli PN, Al-Ahmad A, Hoth-Hannig W, Hannig M and Hannig C: Comparison of different live/dead stainings for detection and quantification of adherent microorganisms in the initial oral biofilm. Clin Oral Investig 17: 841-850, 2013.

53. Grudzinski IP, Bystrzejewski M, Cywinska MA, Kosmider A, Poplawska M, Cieszanowski A and Ostrowska A: Cytotoxicity evaluation of carbon-encapsulated iron nanoparticles in melanoma cells and dermal fibroblasts. J Nanopart Res 15: 1835, 2013.

54. Livak KJ and Schmittgen TD: Analysis of relative gene expression data using real-time quantitative PCR and the 2(-Delta Delta C(T)) method. Methods 25: 402-408, 2001.

55. Yan F, Wu H, Liu H, Deng Z, Liu H, Duan W, Liu X and Zheng H: Molecular imaging-guided photothermal/photodynamic therapy against tumor by iRGD-modified indocyanine green nanoparticles. J Control Release 224: 217-228, 2016.

56. Dong Z, Gong H, Gao M, Zhu W, Sun X, Feng L, Fu T, Li Y and Liu Z: Polydopamine nanoparticles as a versatile molecular loading platform to enable imaging-guided cancer combination therapy. Theranostics 6: 1031-1042, 2016.

57. Matés JM and Sánchez-Jiménez FM: Role of reactive oxygen species in apoptosis: Implications for cancer therapy. Int J Biochem Cell Biol 32: 157-170, 2000.

58. Aioub M,Panikkanvalappil SR and El-Sayed MA: Platinum-coated gold nanorods: Efficient reactive oxygen scavengers that prevent oxidative damage toward healthy, untreated cells during plasmonic photothermal therapy. ACS Nano 11: 579-586, 2017.

59. Oliva CR, Moellering DR, Gillespie GY and Griguer CE: Acquisition of chemoresistance in gliomas is associated with increased mitochondrial coupling and decreased ROS production. PLoS One 6: e24665, 2011.
60. Liu B, Li C, Xing B, Yang P and Lin J: Multifunctional UCNPs@ PDA-ICG nanocomposites for upconversion imaging and combined photothermal/photodynamic therapy with enhanced antitumor efficacy. J Mater Chem B 4: 4884-4894, 2016.

61. Stupp R, van den Bent MJ and Hegi ME: Optimal role of temozolomide in the treatment of malignant gliomas. Curr Neurol Neurosci Rep 5: 198-206, 2005.

62. Samali A, Holmberg CI, Sistonen L and Orrenius S: Thermotolerance and cell death are distinct cellular responses to stress: Dependence on heat shock proteins. FEBS Lett 461: 306-310, 1999.

63. Johnstone RW, Ruefli AA and Lowe SW: Apoptosis: A link between cancer genetics and chemotherapy. Cell 108: 153-164, 2002.

64. Reed JC: Apoptosis-targeted therapies for cancer. Cancer Cell 3: $17-22,2003$.

65. Mohammadinejad R, Moosavi MA, Tavakol S, Vardar DÖ Hosseini A, Rahmati M, Dini L, Hussain S, Mandegary A and Klionsky DJ: Necrotic, apoptotic and autophagic cell fates triggered by nanoparticles. Autophagy 15: 4-33, 2019.

66. Mocan L, Matea C, Tabaran FA, Mosteanu O, Pop T, Mocan T and Iancu C: Photothermal treatment of liver cancer with albumin-conjugated gold nanoparticles initiates Golgi Apparatus-ER dysfunction and caspase-3 apoptotic pathway activation by selective targeting of Gp60 receptor. Int J Nanomed 10: $5435,-5445,2015$.

67. Hongmei Z: Extrinsic and intrinsic apoptosis signal pathway review. In: Apoptosis and Medicine In Tech Open, 2012.

68. Haupt S, Berger M, Goldberg Z and Haupt Y: Apoptosis-the p53 network. J Cell Sci 116: 4077-4085, 2003.

69. Perfettini JL, Reed JC, Israël N, Martinou JC, Dautry-Varsat A and Ojcius DM: Role of Bcl-2 family members in caspase-independent apoptosis during Chlamydia infection. Infect Immun 70: 55-61, 2002.

70. Yee $\mathrm{C}$, Yang $\mathrm{W}$ and Hekimi S: The intrinsic apoptosis pathway mediates the pro-longevity response to mitochondrial ROS in C. elegans. Cell 157: 897-909, 2014.

71. Andón FT and Fadeel B: Programmed cell death: Molecular mechanisms and implications for safety assessment of nanomaterials. Acc Chem Res 46: 733-742, 2012. 